Prepared in cooperation with the Bureau of Land Management and Central Valley Regional Water Quality Control Board

\title{
Wetland Management and Rice Farming Strategies to Decrease Methylmercury Bioaccumulation and Loads from the Cosumnes River Preserve, California
}

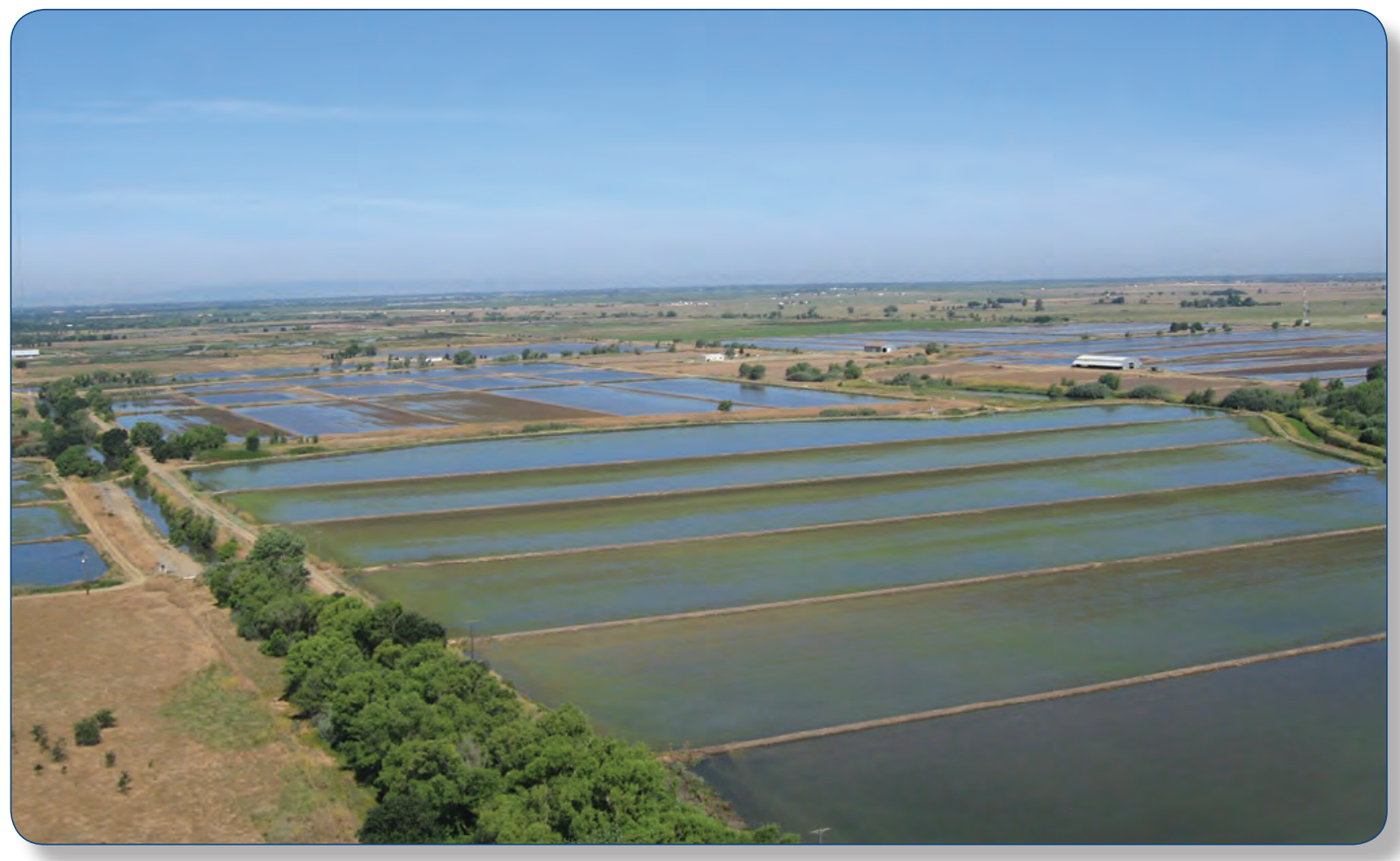

Open-File Report 2014-1172 
Cover: Photograph showing Cosumnes River Preserve, Galt, California, facing west. Photograph taken by Harry Mc Quillen, Bureau of Land Management, June 23, 2010. 


\section{Wetland Management and Rice Farming Strategies to Decrease Methylmercury Bioaccumulation and Loads from the Cosumnes River Preserve, California}

By Collin A. Eagles-Smith, Josh T. Ackerman, Jacob Fleck, Lisamarie Windham-Myers, Harry McQuillen, and Wes Heim

Final Report for the Bureau of Land Management and

Central Valley Regional Water Quality Control Board

Open-File Report 2014-1172 


\section{U.S. Department of the Interior \\ SALLY JEWELL, Secretary}

\section{U.S. Geological Survey \\ Suzette M. Kimball, Acting Director}

U.S. Geological Survey, Reston, Virginia: 2014

For more information on the USGS-the Federal source for science about the Earth,

its natural and living resources, natural hazards, and the environment-visit

http://www.usgs.gov or call 1-888-ASK-USGS

For an overview of USGS information products, including maps, imagery, and publications, visit $h$ ttp://www.usgs.gov/pubprod

To order this and other USGS information products, visit $h$ ttp://store.usgs.gov

Suggested citation:

Eagles-Smith, C.A., Ackerman, J.T., Fleck, J.A., Windham-Myers, L., McQuillen, H., and Heim, W., 2014, Wetland management and rice farming strategies to decrease methylmercury bioaccumulation and loads from the Cosumnes River Preserve, California: U.S. Geological Survey Open-File Report 2014-1172, 42 p., http://dx.doi.org/10.3133/ofr20141172.

ISSN 2331-1258 (online)

Any use of trade, firm, or product names is for descriptive purposes only and does not imply endorsement by the U.S. Government.

Although this information product, for the most part, is in the public domain, it also may contain copyrighted materials as noted in the text. Permission to reproduce copyrighted items must be secured from the copyright owner. 


\section{Contents}

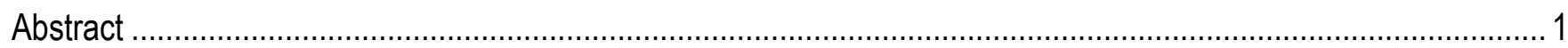

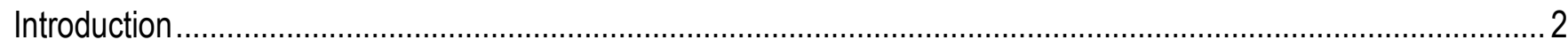

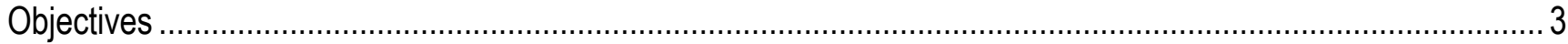

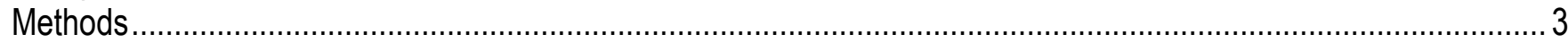

Study Site

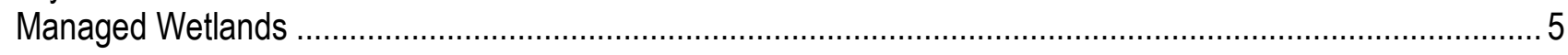

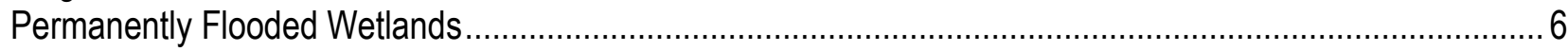

Seasonal Wetlands: Dual Drawdown and Flood-Up Events ………........................................................

Seasonal Wetlands: Single Drawdown and Flood-Up Event ………....................................................

Rice Agricultural Wetlands ..................................................................................................................

Harvest and Chop Straw Management .........................................................................................

Harvest, Chop, and Disk Straw Management .............................................................................

Harvest, Chop, Bale, and Bale Removal Straw Management............................................................... 8

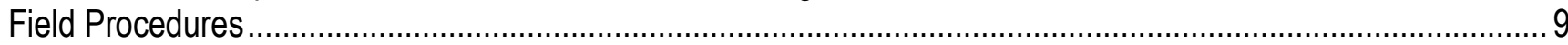

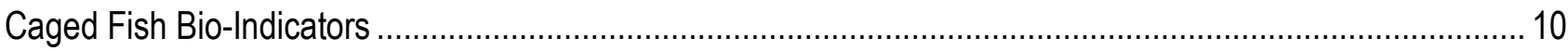

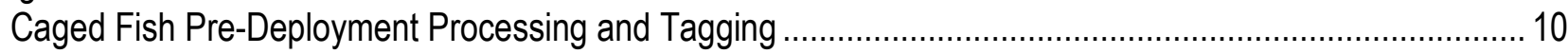

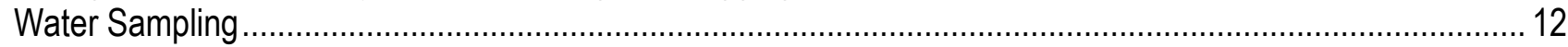

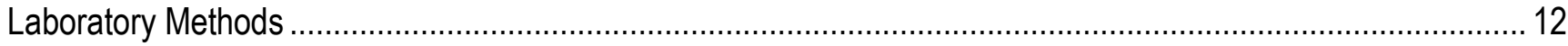

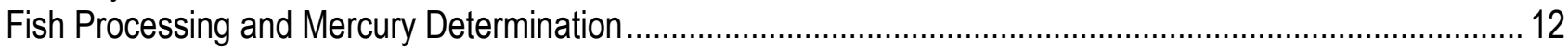

Water Mercury Determination and Ancillary Parameters ....................................................................... 12

Quality Assurance/Quality Control.................................................................................................. 13

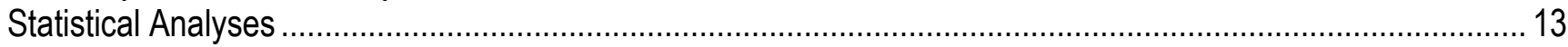

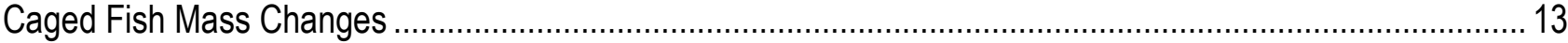

Habitat Differences in Caged Fish Mercury ........................................................................................ 13

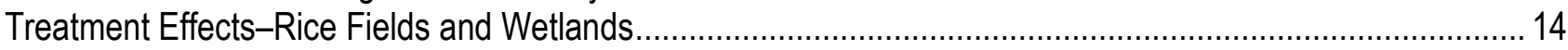

Habitat Effects-Rice Fields and Seasonal Wetlands with Matching Hydrology ............................................ 14

Treatment Effects on Aqueous Methylmercury Concentrations ................................................................. 14

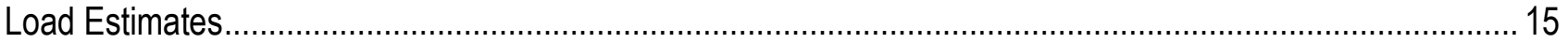




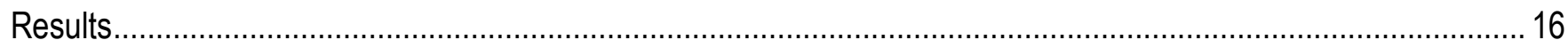

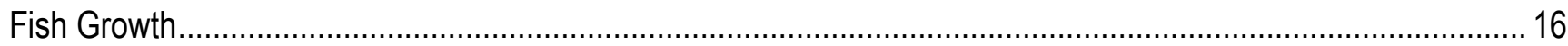

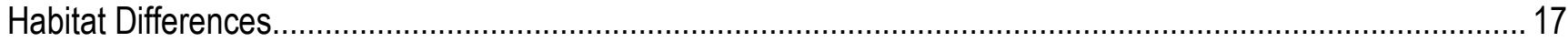

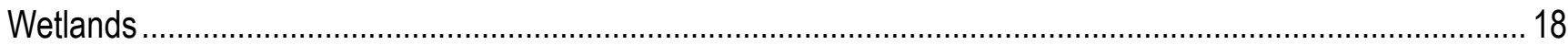

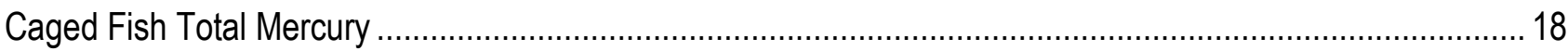

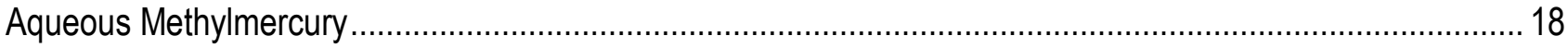

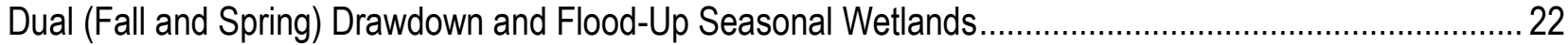

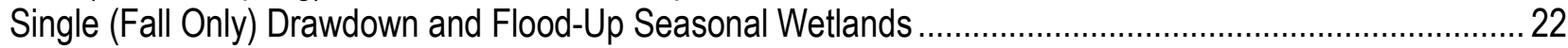

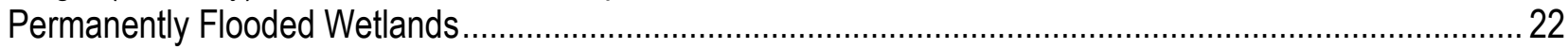

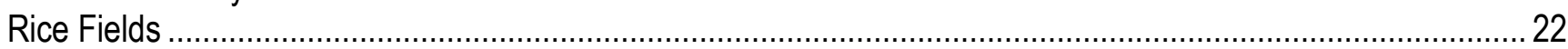

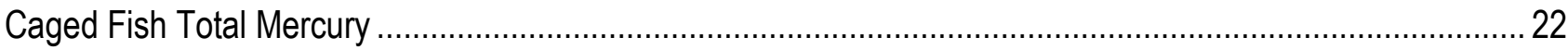

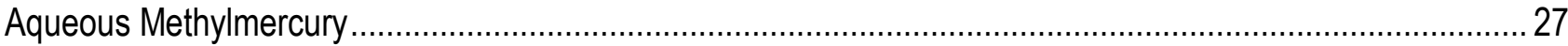

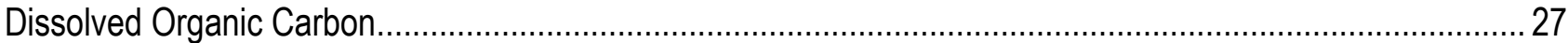

Habitat Effects-Rice Fields and Seasonal Wetlands with Matching Hydrology.................................................27

Correlations Between Fish Total Mercury and Water Methylmercury .............................................................. 33

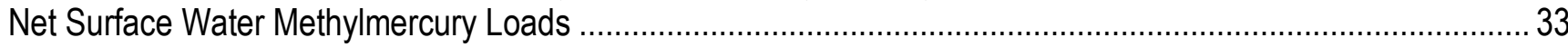

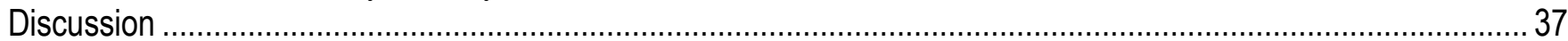

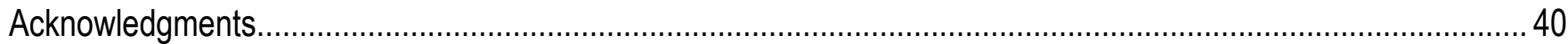

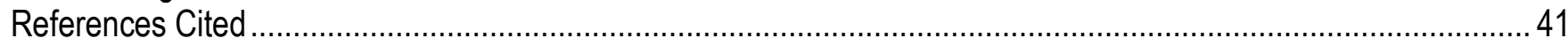

\section{Figures}

Figure 1. Map showing location of Cosumnes River Preserve in the Cosumnes River watershed, California .......... 4

Figure 2. Schematic showing flooding regimes for seasonally flooded managed wetlands and rice fields ............... 5

Figure 3. Map showing permanent and seasonal wetland locations, Cosumnes River Preserve, California ............ 6

Figure 4. Map showing rice fields sampled in this study, Cosumnes River Preserve, California.............................. 8

Figure 5. Photographs showing post-harvest rice field treatment .................................................................... 9

Figure 6. Photographs showing mobile aquaculture and holding pools (center), cage deployed in wetland (upper right), western mosquitofish (Gambusia affinis) with elastomer tags along dorsal fin (bottom left and bottom right)

Figure 7. Relationship between change in fish mass ( $\Delta$ mass) and initial fish mass after 30 deployments in cages. Top two panels represent $\Delta$ mass (mass at retrieval - mass at deployment) versus initial fish mass at tagging during the summer (left) and winter (right) deployment time periods.

Figure 8. Caged fish total mercury ( $\mathrm{THg}$ ) concentrations (least-square mean \pm standard error) across habitats in the Cosumnes River Preserve after 30 days of deployment.

Figure 9. Total mercury (THg) concentrations (least-square mean \pm standard error) from caged fish placed at the inlets (gray bars) and outlets (black bars) of permanently inundated, single (fall-only) drawdown and flood-up, and dual (fall and spring) drawdown and flood-up managed wetlands in the Cosumnes River Preserve during summer 2011, winter 2011-12, and summer 2012

Figure 10. Temporal variation in unfiltered aqueous methylmercury $(\mathrm{MeHg})$ concentrations $(\mathrm{ng} / \mathrm{L})$ from managed wetlands in the Cosumnes River Preserve between June 2011 and September 2012. 
Figure 11. Aqueous methylmercury (MeHg) concentrations (unfiltered, ng/L) in inlets (black bars) and outlets (gray bars) of (A) dual drawdown seasonal wetlands, (B) single drawdown seasonal wetlands, and $(\mathrm{C})$ permanent wetlands in the Cosumnes River Preserve

Figure 12. Relationship between aqueous methylmercury ( $\mathrm{MeHg}$ ) concentrations ( $\mathrm{ng} / \mathrm{L}$ unfiltered) and dissolved organic carbon (DOC) concentrations in dual drawdown seasonal wetlands in the Cosumnes River Preserve

Figure 13. Relationship between aqueous methylmercury ( $\mathrm{MeHg}$ ) concentrations ( $\mathrm{ng} / \mathrm{L}$ unfiltered) and day-of-year in permanent wetlands in the Cosumnes River Preserve.

Figure 14. Relationship between aqueous methylmercury ( $\mathrm{MeHg}$ ) concentrations ( $\mathrm{ng} / \mathrm{L}$ unfiltered) and dissolved organic carbon (DOC) concentrations in permanent wetlands in the Cosumnes River Preserve 25

Figure 15. Total mercury ( $\mathrm{THg}$ ) concentrations (least squared mean \pm standard error) from caged fish placed at the inlets (gray bars) and outlets (black bars) of rice fields subjected to one of three post-harvest straw management treatments in the Cosumnes River Preserve during summer 2011, winter 2011-12, and summer 2012.

Figure 16. Temporal variation in unfiltered aqueous methylmercury $(\mathrm{MeHg})$ concentrations $(\mathrm{ng} / \mathrm{L})$ from rice fields in the Cosumnes River Preserve between June 2011 and September 2012

Figure 17. Aqueous methylmercury (MeHg) concentrations in rice fields versus days post flood-up in summer (top panel) and winter (bottom panel) in the Cosumnes River Preserve.

Figure 18. Seasonal differences in aqueous methylmercury (MeHg) concentrations (unfiltered, $n g / L$ ) in rice fields in the Cosumnes River Preserve.

Figure 19. Relationship between aqueous methylmercury ( $\mathrm{MeHg}$ ) concentrations (unfiltered $\mathrm{ng} / \mathrm{L}$ ) and dissolved organic carbon (DOC) from rice fields in the Cosumnes River Preserve

Figure 20. Dissolved organic carbon (DOC) concentrations from inlet and outlet surface-water samples of rice fields subjected to three post-harvest rice straw management practices in the Cosumnes River Preserve during summer 2011, winter 2011-12, and summer 2012.

Figure 21. Caged fish THg concentrations (least-square mean \pm standard error) from inlets and outlets of rice fields and managed seasonal wetlands subjected to identical wetting and drying cycles 32

Figure 22. Relationship between cage-specific mean fish total mercury concentrations and seasonal average aqueous methylmercury concentrations in rice fields (top panel) and seasonal wetlands (bottom panel) during summer (filled circles) and winter (open circles) time periods in the Cosumnes River Preserve 34

Figure 23. Boxplot showing net methylmercury (MeHg) loads by season in the Cosumnes River Preserve 35

\section{Table}

Table 1. Estimated net methylmercury ( $\mathrm{MeHg}$ ) loads from rice fields. Six unique solutions evaluated with eight scenarios using evapotranspiration (ET), flow, and salt (Cl or EC). 


\section{Conversion Factors}

\section{SI to Inch/Pound}

\begin{tabular}{lcl}
\hline \multicolumn{1}{c}{ Multiply } & By & \multicolumn{1}{c}{ To obtain } \\
\hline millimeter (mm) & Length & \\
meter (m) & 0.03937 & inch (in.) \\
kilometer (km) & 3.281 & foot (ft) \\
\hline \multicolumn{3}{c}{ Volume } \\
\hline liter (L) & 0.6214 & mile (mi) \\
\hline & 33.82 & ounce, fluid (fl. oz) \\
\hline gram (g) & Mass & \\
\hline & 0.03527 & ounce, avoirdupois (oz) \\
\hline hectare (ha) & Area & \\
\hline
\end{tabular}

Temperature in degrees Celsius $\left({ }^{\circ} \mathrm{C}\right)$ may be converted to degrees Fahrenheit $\left({ }^{\circ} \mathrm{F}\right)$ as follows: ${ }^{\circ} \mathrm{F}=\left(1.8 \mathrm{x}^{\circ} \mathrm{C}\right)+32$. 


\title{
Wetland Management and Rice Farming Strategies to Decrease Methylmercury Bioaccumulation and Loads from the Cosumnes River Preserve, California
}

By Collin A. Eagles-Smith¹, Josh T. Ackerman ${ }^{1}$, Jacob Fleck¹, Lisamarie Windham-Myers ${ }^{1}$, Harry McQuillen², and Wes Heim ${ }^{3}$

\begin{abstract}
We evaluated mercury ( $\mathrm{Hg}$ ) concentrations in caged fish (deployed for 30 days) and water from agricultural wetland (rice fields), managed wetland, slough, and river habitats in the Cosumnes River Preserve, California. We also implemented experimental hydrological regimes on managed wetlands and post-harvest rice straw management techniques on rice fields in order to evaluate potential Best Management Practices to decrease methylmercury bioaccumulation within wetlands and loads to the Sacramento-San Joaquin River Delta. Total Hg concentrations in caged fish were twice as high in rice fields as in managed wetland, slough, or riverine habitats, including seasonal managed wetlands subjected to identical hydrological regimes. Caged fish $\mathrm{Hg}$ concentrations also differed among managed wetland treatments and post-harvest rice straw treatments. Specifically, Hg concentrations in caged fish decreased from inlets to outlets in seasonal managed wetlands with either a single (fall-only) or dual (fall and spring) drawdown and flood-up events, whereas $\mathrm{Hg}$ concentrations increased slightly from inlets to outlets in permanent managed wetlands. In rice fields, experimental post-harvest straw management did not decrease $\mathrm{Hg}$ concentrations in caged fish. In fact, in fields in which rice straw was chopped and either disked into the soil or baled and removed from the fields, fish $\mathrm{Hg}$ concentrations increased from inlets to outlets and were higher than $\mathrm{Hg}$ concentrations in fish from rice fields subjected to the more standard post-harvest practice of simply chopping rice straw prior to fall flood-up. Finally, aqueous methylmercury ( $\mathrm{MeHg}$ ) concentrations and export were highly variable, and seasonal trends in particular were often opposite to those of caged fish. Aqueous $\mathrm{MeHg}$ concentrations and loads were substantially higher in winter than in summer, whereas caged fish $\mathrm{Hg}$ concentrations were relatively low in winter and substantially higher in summer. Together, our results highlight the importance of habitat, seasonal processes, and wetland management practices on $\mathrm{Hg}$ cycling and ecological risk in aquatic ecosystems.
\end{abstract}

\footnotetext{
${ }^{1}$ U.S. Geological Survey.

${ }^{2}$ Bureau of Land Management.

${ }^{3}$ Moss Landing Marine Laboratory, California.
} 


\section{Introduction}

Mercury $(\mathrm{Hg})$ contamination is widespread in aquatic ecosystems because atmospheric emissions from both natural and anthropogenic sources distribute $\mathrm{Hg}$ globally (Driscoll and others, 2013). At local and regional scales, point sources of $\mathrm{Hg}$, such as mining activity, can further extend the distribution of $\mathrm{Hg}$ through the environment by hydrologic transport (Singer and others, 2013). Once deposited into aquatic ecosystems, inorganic $\mathrm{Hg}$ can be converted to methylmercury ( $\mathrm{MeHg}$ ) by microbial processes (Ullrich and others, 2001). Methylmercury production is enhanced in wetlands because they often contain biogeochemical characteristics that facilitate the $\mathrm{MeHg}$-producing microbial activity (Hall and others, 2008). In the Sacramento-San Joaquin River Delta of California's Central Valley, $\mathrm{Hg}$ contamination is a priority issue because historical $\mathrm{Hg}$ mining in the Coast Range and gold mining in the Sierra Nevada Mountains have resulted in extensive inorganic Hg contamination of wetland and floodplain habitats throughout the Central Valley and the Sacramento-San Joaquin River Delta (Heim and others, 2007).

California's Central Valley and the Sacramento-San Joaquin River Delta contain many freshwater wetlands and floodplains that could facilitate $\mathrm{MeHg}$ production and loading into the Delta. Although approximately 90 percent of the natural wetlands in the region have been lost to development (Frayer and others, 1989), there are extensive ongoing and planned wetland restoration projects to enhance existing wetlands and restore historical wetlands. This network of created, restored, and managed wetlands throughout the region supports winter migratory waterfowl and native fishes, some of which are listed as Federal and/or State threatened and endangered species. A large proportion of the wetland habitat that remains in the region is comprised of rice agriculture, which has been shown to promote elevated $\mathrm{Hg}$ bioaccumulation in fishes relative to non-agricultural wetlands (Ackerman and Eagles-Smith, 2010). The amount of winter-flooded rice fields increased 47 percent between 1990 and 2000 in response to the ban on the once common practice of burning residual rice straw (Fleskes and others, 2005; Ackerman and others, 2006). Additionally, the total amount of land area in rice production within the Central Valley has increased considerably, at least in part because of the increase in the price of rice.

As a result of extensive MeHg contamination, the Sacramento-San Joaquin River Delta is listed as a Clean Water Act Section 303(d) impaired water body, and a Total Maximum Daily Load (TMDL) has been developed by the Central Valley Regional Water Quality Control Board (Wood and others, 2010). Numerical target values for this TMDL include small trophic level 2 and 3 fish species less than $50 \mathrm{~mm}$ in length with $\mathrm{Hg}$ concentrations less than $0.03 \mu \mathrm{g} / \mathrm{g}$ wet weight, and aqueous $\mathrm{MeHg}$ concentrations less than $0.06 \mathrm{ng} / \mathrm{L}$. Phase I implementation of the TMDL includes a requirement for non-point source dischargers (including managers of wetlands) to conduct control studies to test potential Best Management Practices (BMPs) for minimizing MeHg production, discharge, and loading to the Delta. One of the primary goals of the TMDL process is to develop feasible BMPs that will decrease $\mathrm{MeHg}$ loading from wetlands, agricultural lands, and other habitat types, while still maintaining their intended biological functions at acceptable economical and ecological costs.

There are a limited number of strategies to decrease MeHg loading into the Sacramento-San Joaquin River Delta, but two of the most practical strategies include (1) decreasing the flow of water leaving the wetlands, and (2) decreasing the concentrations of $\mathrm{MeHg}$ in the outflowing water. However, the ecological needs of wetlands and other habitats for adequate water in-flow limits the feasibility of reducing water outflow in many instances. Therefore, developing approaches for decreasing $\mathrm{MeHg}$ concentrations in outflowing water may have the greatest likelihood of success and adoption. 
Controlling onsite $\mathrm{MeHg}$ production is an attractive option for decreasing $\mathrm{MeHg}$ concentrations in outflowing water because it would provide the added benefit of decreasing in situ $\mathrm{Hg}$ bioaccumulation (and therefore local wildlife exposure) within wetland habitats, which is not a requirement under TMDL regulation. $\mathrm{MeHg}$ is produced by anaerobic bacteria within wetlands, and the efficiency and rate of methylation is facilitated by the biogeochemical conditions of their environment (Ullrich and others, 2001). Although the processes are complex, key components in MeHg cycling include (1) bioavailable inorganic $\mathrm{Hg}$; (2) available sulfate, iron, or other appropriate electron acceptors (Gilmour and others, 1992; Fleming and others, 2006); (3) limited sulfide concentrations (Marvin-Di Pasquale and Agee, 2003); and (4) a labile organic carbon source (Lambertsson and Nilsson, 2006; Windham-Myers and others, 2009). The relative importance of these components can vary over space and time. Within wetlands and rice fields of the Yolo Bypass Wildlife Area of California's Central Valley, labile organic carbon was an important limiting factor (Windham-Myers and others, 2014a). Thus, control of available labile organic carbon in wetlands could be an effective approach towards decreasing $\mathrm{MeHg}$ production, and ultimately $\mathrm{MeHg}$ export.

In this study, we tested whether organic matter controls in rice fields could decrease aqueous $\mathrm{MeHg}$ concentrations, $\mathrm{Hg}$ bioaccumulation in fishes, and $\mathrm{MeHg}$ loads from fields to the SacramentoSan Joaquin River Delta. Additionally, we assessed how manipulation of wetland flooding patterns might alter Hg cycling within non-agricultural managed wetlands.

\section{Objectives}

The objectives for this study were:

- Objective 1: Compare $\mathrm{Hg}$ concentrations in fish and water among primary wetland habitats (Cosumnes River, rice fields, managed wetlands, sloughs, and internal canals) of the Cosumnes River Preserve (Preserve).

- Objective 2: Test effects of altering the timing and duration of managed wetland flooding on $\mathrm{Hg}$ concentrations in fish and water.

- Objective 3: Test effects of post-harvest rice straw management on $\mathrm{Hg}$ concentrations in fish and water.

\section{Methods}

\section{Study Site}

This study focused on approximately 243 ha of seasonal wetland, permanent wetland, and rice agriculture habitats, as well as the Cosumnes River itself and several sloughs and channels that were hydrologically connected with the mainstem of the Cosumnes River.

The Cosumnes River watershed drains 198,900 ha of the western Sierra Nevada (fig. 1). Much of the lower portion of the watershed is part of the Preserve, which encompasses more than 20,000 hectares of wetland, upland, and agricultural land. The Preserve is owned by a consortium of seven land-owning partners (The Nature Conservancy, Bureau of Land Management, California Department of Fish and Wildlife, Sacramento County, California Department of Water Resources, Ducks Unlimited, and the California State Lands Commission), and is managed by the Bureau of Land Management for the protection of a continuous riparian corridor extending from the Cosumnes River 
headwaters to the Sacramento-San Joaquin Delta. The Preserve is comprised of a mosaic of habitats that include floodplains, vernal pool grasslands, seasonal and permanent wetlands, valley oak (Quercus lobata) woodlands, and wildlife-compatible agriculture. This diversity of habitats supports an abundance of native and non-native plants, fish, and wildlife (including thousands of wintering waterbirds and several special status species, such as sandhill cranes [Grus canadensis], giant garter snake [Thamnophis gigas], western pond turtle [Actinemys marmorata], and native fish species). It is also an especially important habitat for migratory waterfowl.

Previous mining activities in the upper portion of the watershed have resulted in extensive $\mathrm{Hg}$ contamination within the Cosumnes River and the fluvial plain of the lower watershed. The abundance of restored and managed wetlands and floodplains within the lower Cosumnes River watershed facilitates $\mathrm{MeHg}$ production, resulting in elevated discharges to the Sacramento-San Joaquin River Delta. However, the floodplains and wetlands also are important habitat for rearing native fishes, supporting wintering migratory birds, and improving overall ecosystem function and services of the area. Therefore, it is critical to protect and expand these wetland habitats while also reducing $\mathrm{MeHg}$ export to the downstream environments of the Sacramento-San Joaquin River Delta and contamination to resident biota that use local wetlands.

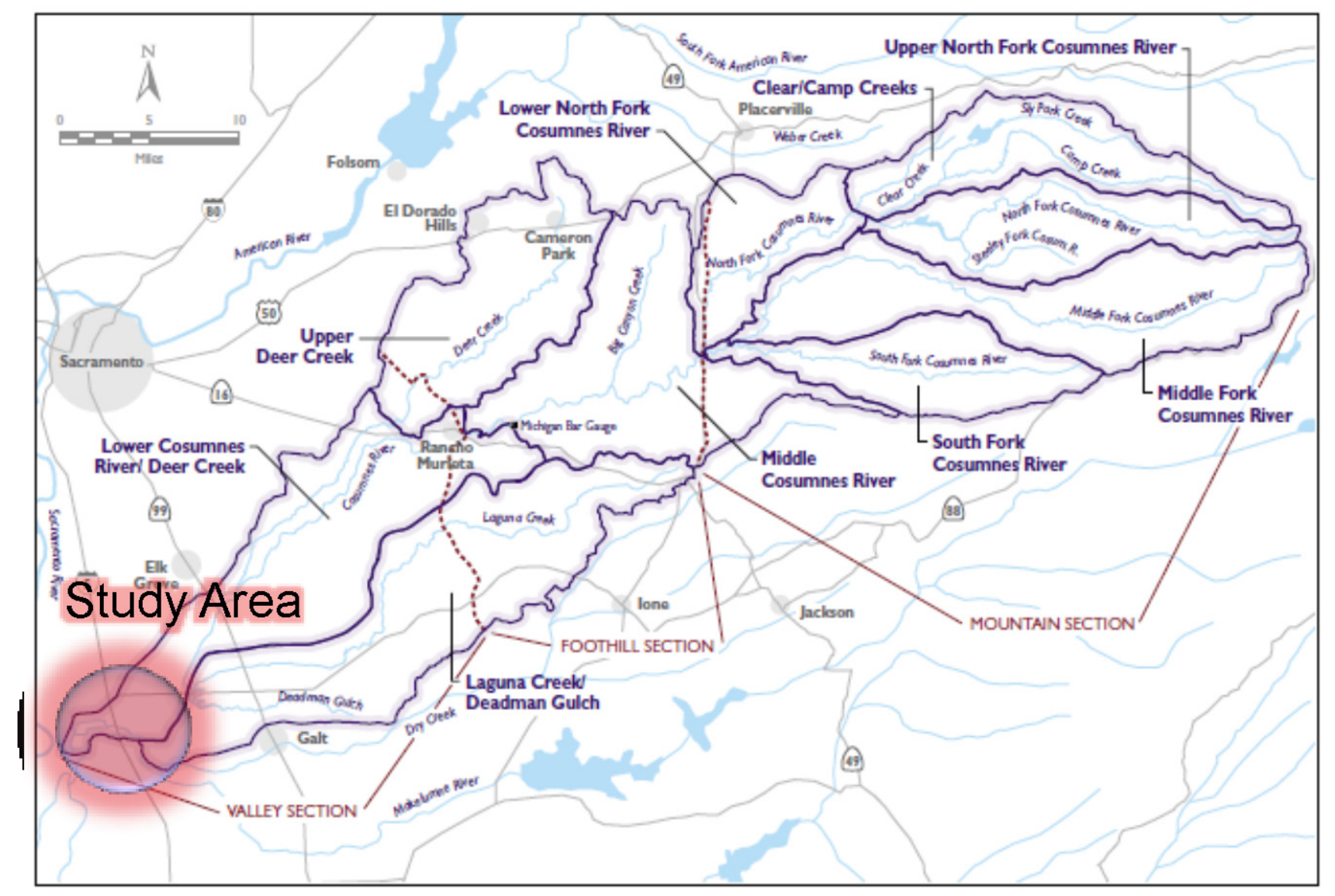

Figure 1. Map showing location of Cosumnes River Preserve in the Cosumnes River watershed, California. 


\section{Managed Wetlands}

Managed wetland habitats in the Preserve can be classified as either seasonal wetlands (experience regular wetting and drying patterns), or permanent wetlands (remain permanently inundated with water year-round). The specific timing and duration of wetland inundations generally are managed in response to wildlife habitat goals that are defined by the Preserve's Annual Wetlands Operation Plan. For the purposes of this study, we manipulated water flooding schedules in order to examine the influence of timing and duration of water inundation on $\mathrm{MeHg}$ concentrations in fish and water. Specifically, we conducted the study in three permanently flooded wetlands, three seasonally flooded wetlands with dual (spring and fall) drawdown and flood-up events, and three seasonally flooded wetlands that had only a single (fall-only) drawdown and flood-up event (fig. 2). All nine wetlands were of a similar depth (approximately $1 \mathrm{~m}$ ), and constrained by earthen levees where water flow was controlled by an inlet control valve and an outlet drain box. All irrigation water was delivered to seasonal wetlands through a single pump at a nearby slough, whereas each permanent wetland was fed by individual pumps located in adjacent sloughs.

\section{Rice fields and dual draw-down and flood-up wetlands}

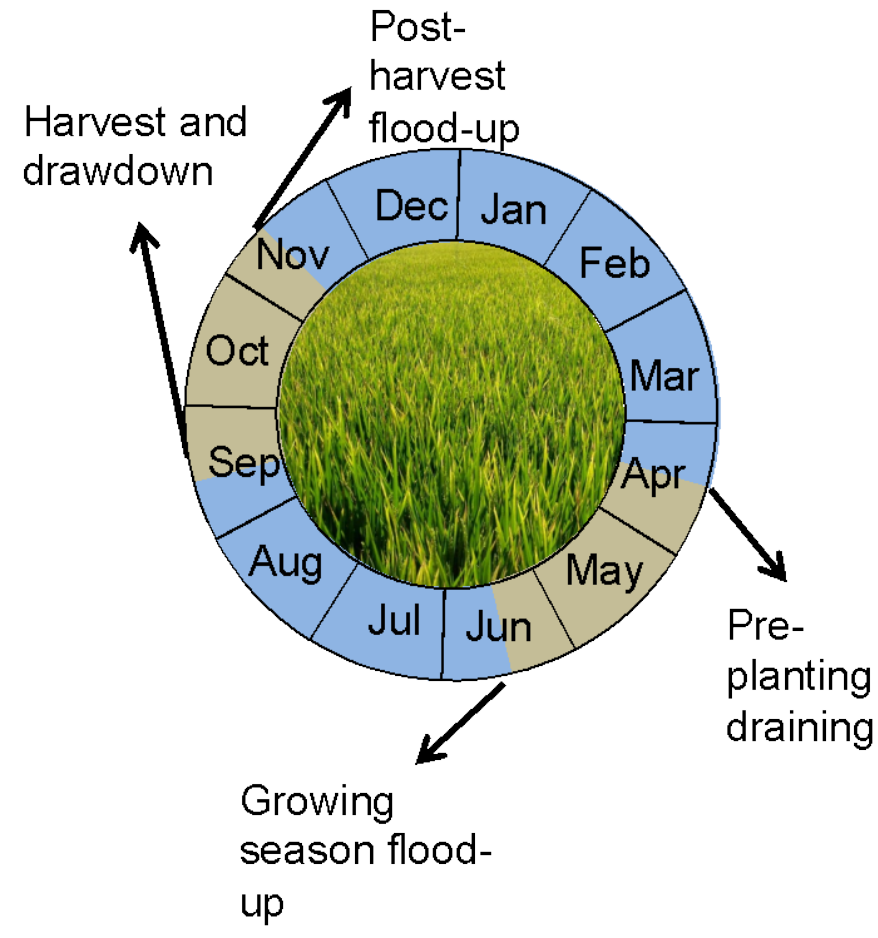

\section{Single draw-down and flood-up wetlands}

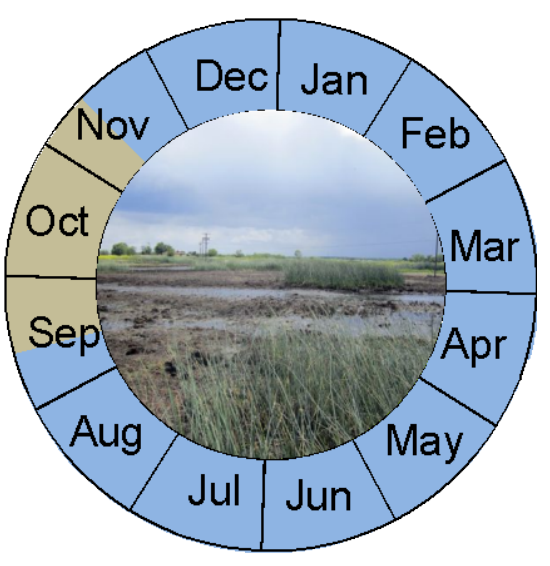

Figure 2. Schematic showing flooding regimes for seasonally flooded managed wetlands and rice fields. Blue shading represents periods of water inundation. Beige shading indicates periods of drawdown. The left panel is for rice fields and dual (fall and spring) drawdown and flood-up seasonal wetlands that were managed under identical hydrological regimes. The right panel represents single (fall only) drawdown and flood-up seasonal wetlands. 


\section{Permanently Flooded Wetlands}

Permanently flooded wetlands in this study included Pond 28, Pond 3A, and Pond TC-1 (fig. 3). All three wetlands were located along the western portion of the Preserve. Each wetland remained inundated through the duration of this study. Every effort was made to minimize water- level fluctuations by activating pumps on a regular basis. Ponds 28 and 3A were densely vegetated, predominantly with tule (Scheonoplectus acutus), whereas Pond TC-1 was largely open water with a section of dense tule.

\section{Seasonal Wetlands: Dual Drawdown and Flood-Up Events}

The seasonal wetlands with spring and fall drawdown and flood-up events included Ponds 20, 25, and 26 (fig. 3). The hydrology of these wetlands was managed to mimic the hydrology of rice fields. Specifically, each wetland was flooded in mid-November through mid-April, drained mid-April through mid-June, flooded again in mid-June through mid-September, then drained again in mid-September through mid-November at the same times when rice fields were flooded (fig. 2). This hydrological regime was maintained for approximately 3 years.
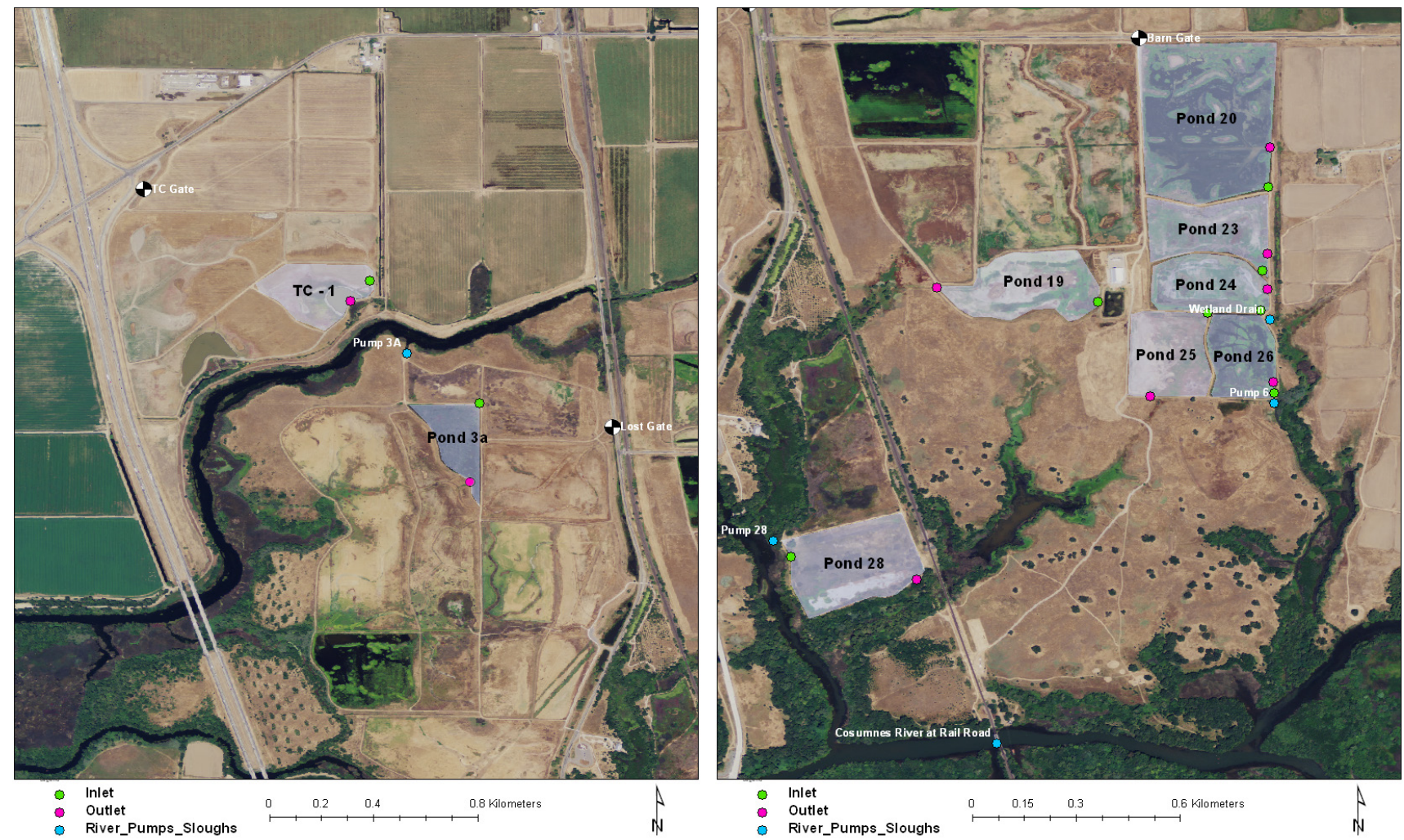

Figure 3. Map showing permanent and seasonal wetland locations, Cosumnes River Preserve, California. Green dots represent water inlet locations where water and caged fish were sampled. Pink dots represent water outlet locations where water, sediment, and caged fish were sampled; Blue dots represent river, slough, or canal locations where water and caged fish were sampled. 


\section{Seasonal Wetlands: Single Drawdown and Flood-Up Event}

The seasonal wetlands with fall-only drawdown and flood-up events included Ponds 19, 23, and 24 (fig. 3). The hydrology of these wetlands was managed to be intermediate between the permanently flooded wetlands and the dual flood-up and drawdown wetlands. Specifically, drawdown periods were identical to the fall drawdown events (mid-September through mid-November) of the seasonal wetlands experiencing the dual drawdown and flood-up events. The seasonal wetlands remained fully inundated throughout the remainder of the year.

\section{Rice Agricultural Wetlands}

We studied a total of nine rice fields and implemented three post-harvest straw management actions with three replicate fields for each (figs. 4 and 5). As is standard practice for rice agriculture in California, each rice field was constructed with a series of internal levees (checks) with a small gate in each check to allow directional gravity flow of water between checks. As with the managed seasonal and permanent wetlands, each rice field received water from a single inlet valve and drained from a single outlet water control structure (rice box) at the most downstream location in the field. However, unlike the seasonal and permanent wetlands, source water for the rice fields originated from two source pumps (F1 and F7) into the supply canals where it was further distributed by additional pump stations to piped field inlets (fig. 1). It took approximately 1 week to flood the fields in the early summer, and water levels were maintained with approximately $0-2 \mathrm{~cm}$ continuous flow over the outlet water control structure through the duration of the growing season. Drawdown at the end of the growing season occurred over approximately 1 week to allow fields to dry for harvest. After harvest, one of three straw management techniques was implemented prior to the fall and winter flood-up. The straw-residue management techniques included (1) harvest and chop (standard harvest); (2) harvest, chop, and disk (chopped and disked); and (3) harvest, chop, bale, and removal of baled rice straw residues from the fields (chopped and baled). All fields were similarly disked in the spring when fields were worked for

preparation of the seedbed prior to planting. In the winter, after fall harvest, rice fields were flooded to a depth of approximately $20 \mathrm{~cm}$ to promote decomposition of rice straw and provide habitat for migrating and overwintering waterfowl.

\section{Harvest and Chop Straw Management}

The rice fields receiving this treatment included fields B-7, B-13, and C-9 (figs. 4 and 5). This procedure followed standard practices implemented in most rice agricultural land in California. After seed harvest, the residual rice straw stubble was chopped to a height of approximately $30 \mathrm{~cm}$, and the residual straw was left in the field where it was allowed to decompose during winter.

\section{Harvest, Chop, and Disk Straw Management}

The rice fields receiving this treatment included fields B-14, B-21, and C-10 (figs. 4 and 5). This procedure consisted of harvesting and chopping the straw as described above, but also included an additional step of disking the soil in the fall, which turned some of the residual rice straw into the soil subsurface before the fields were flooded for the winter. Disking was done using a $25 \mathrm{ft}$ tractor-pulled disk that turned soil to a depth of approximately $20 \mathrm{~cm}$. 


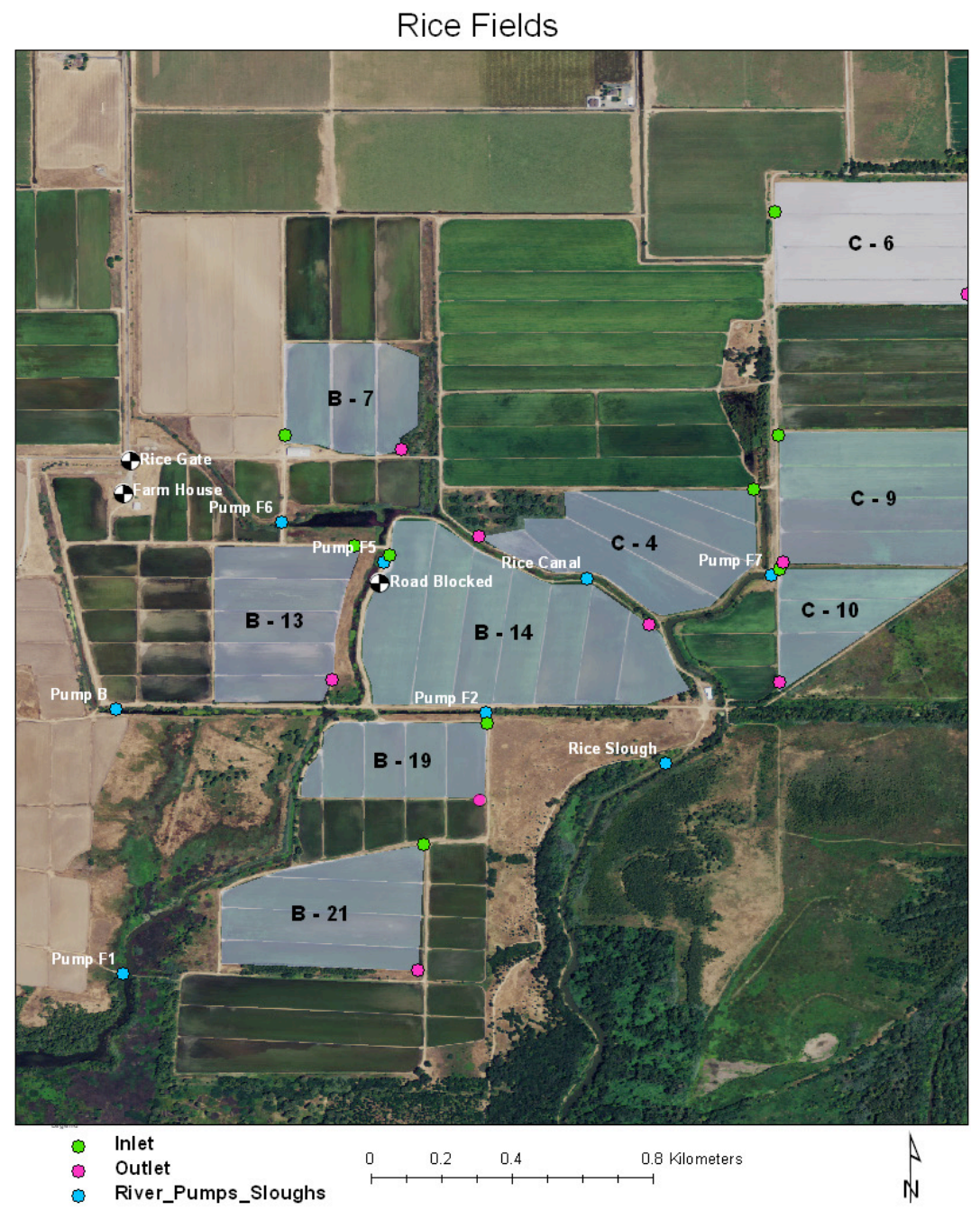

Figure 4. Map showing rice fields sampled in this study, Cosumnes River Preserve, California. Green dots represent water inlet locations where water and caged fish were sampled, pink dots represent water outlet locations where water, caged fish, and sediment were sampled, and blue dots represent river, slough, or canal locations where water and caged fish were sampled.

Harvest, Chop, Bale, and Bale Removal Straw Management

The rice fields receiving this treatment included fields B-19, C-4, and C-6 (figs. 4 and 5). This procedure consisted of harvesting and chopping the straw to approximately $10 \mathrm{~cm}$ (lower than is common practice), followed by baling the residual rice straw and removing the bales from the rice fields before they were flooded for the winter. 

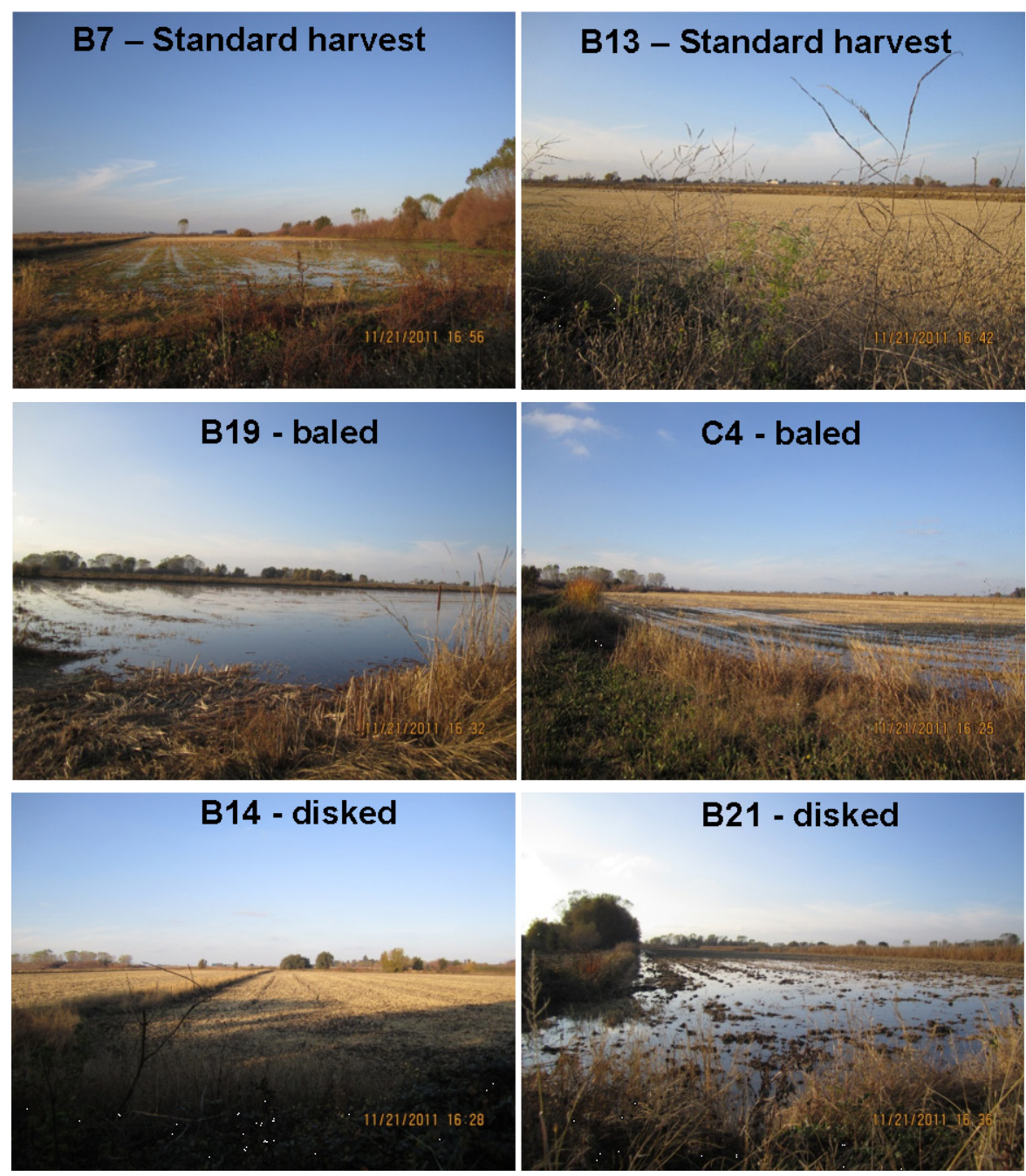
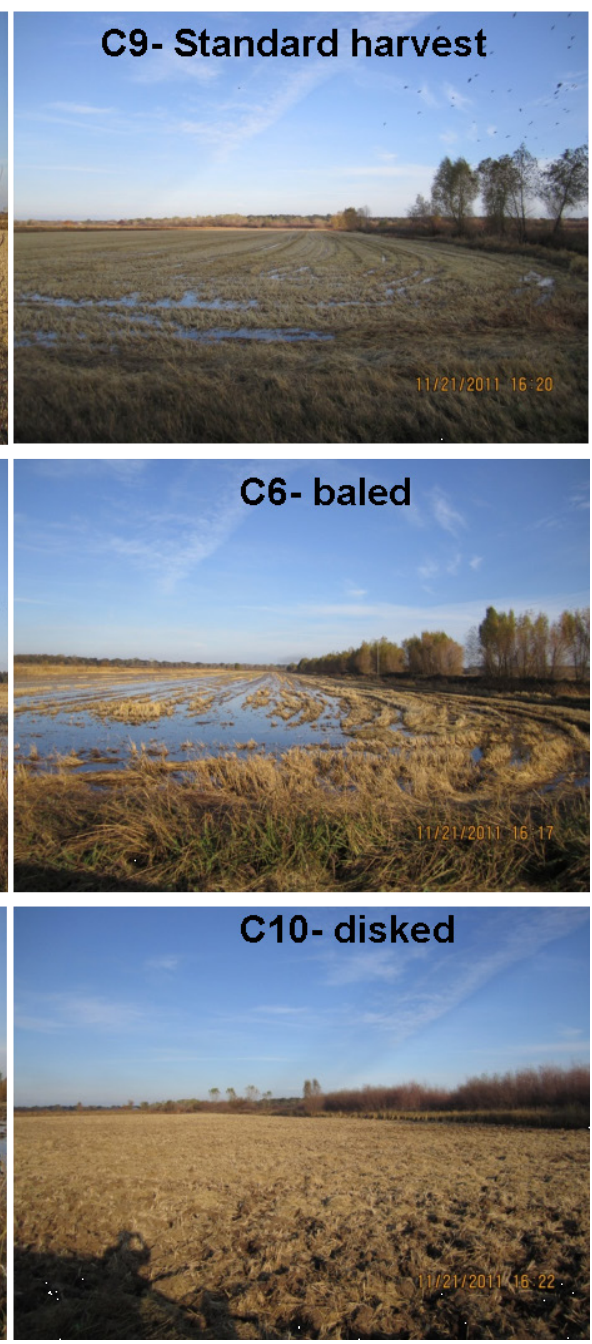

Figure 5. Photographs showing post-harvest rice field treatments.

\section{Field Procedures}

In order to examine the influence of wetland management and rice harvest practices on $\mathrm{Hg}$ concentrations in fish and water, we implemented two distinct approaches. First, we deployed caged western mosquitofish (Gambusia affinis) as bio-indicators of $\mathrm{MeHg}$ availability and bioaccumulation (Ackerman and Eagles-Smith, 2009). Second, we collected surface-water samples for $\mathrm{MeHg}$ concentrations and estimated export (Fleck and others, 2014). 


\section{Caged Fish Bio-Indicators}

The transient and ephemeral processes that control $\mathrm{Hg}$ methylation, demethylation, and transport, combined with the complexities associated with the bioavailability of $\mathrm{MeHg}$, often limit the utility of single-point-in-time measurements of aqueous $\mathrm{MeHg}$ concentrations. However, when combined with other time-integrated measures of $\mathrm{MeHg}$ cycling within wetland habitats, limited aqueous $\mathrm{MeHg}$ measurements can be informative. In this study, we implemented caged western mosquitofish as bio-indicators of $\mathrm{MeHg}$ bioavailability within and across wetlands and rice fields. This is a powerful technique used previously in Central Valley habitats to successfully monitor $\mathrm{Hg}$ bioaccumulation in rice fields and wetlands (Ackerman and Eagles-Smith, 2010). This approach provides an integrative measure of aqueous $\mathrm{MeHg}$ concentrations, which is considered superior to single-point-in-time estimates provided directly by limited, and more highly variable, water concentrations.

\section{Caged Fish Pre-Deployment Processing and Tagging}

We deployed 30 western mosquitofish in individual cages at each site during three discrete events - summer 2011, winter 2011-12, and summer 2012. Prior to each deployment, we obtained mosquitofish from the Sacramento-Yolo County Mosquito and Vector Control District's fish-rearing facility, where they were fed ad libitum and treated for diseases prior to release. Approximately 2,000 individual fish were obtained for each deployment event. Fish were taken from holding tanks within the rearing facility and placed into aerated $180 \mathrm{~L}$ coolers filled with rearing-facility well water. Fish were immediately transported to the Preserve where they were acclimated to site water in a mobile aquaculture facility for approximately 24 hours prior to processing.

Acclimating the fish involved a continuous 30 percent per hour titration of water from wetland inlet pumps into the aerated holding tanks containing rearing-facility well water. After 3 hours, fish were transferred into one of three 1,900 liter holding tanks that received a continuous flow of fresh water from the wetland inlet pumps. Continuous flow was achieved by gravity flow from a central 1,900 liter distribution tank. The central distribution tank was refilled every $6-8$ hours by pumping water from a 7,600 liter water tender that was filled directly at a wetland inlet valve on-site at the Preserve. Each acclimation tank and distribution tank were continuously aerated. All fish were held for approximately 18-20 hours in the acclimation tanks prior to processing.

After acclimating for 18-20 hours, each fish was individually removed from the acclimation tank and placed in a buffered MS-222 solution $(100 \mathrm{mg} / \mathrm{L})$ until they became sedated. Upon sedation, we weighed each fish to the nearest $0.001 \mathrm{~g}$ on a digital balance and measured them to the nearest millimeter on a fish board. We then marked each individual fish with a combination of colored elastomer tags (Northwest Marine Technology, Inc., Shaw Island, Wash.) placed in up to three locations on each fish. Specifically, tags were placed along the dorsal muscle on either the left or right of the fish, as well as at the base of the caudal fin. The combination of four colors and up to three tag locations allowed us to uniquely identify each of the 30 individual fish within each cage. After tagging, we placed each fish in a recovery tank until it regained consciousness, at which point we moved the fish into a labeled flow-through 19 L holding cage within the acclimation pools. Each holding cage was designated for deployment to a specific field location. After all fish were tagged, we held them overnight until we deployed them into their specific cage. Any mortalities prior to a deployment $(<1$ percent) were replaced with newly tagged fish that had the same tag sequence (fig. 6). 


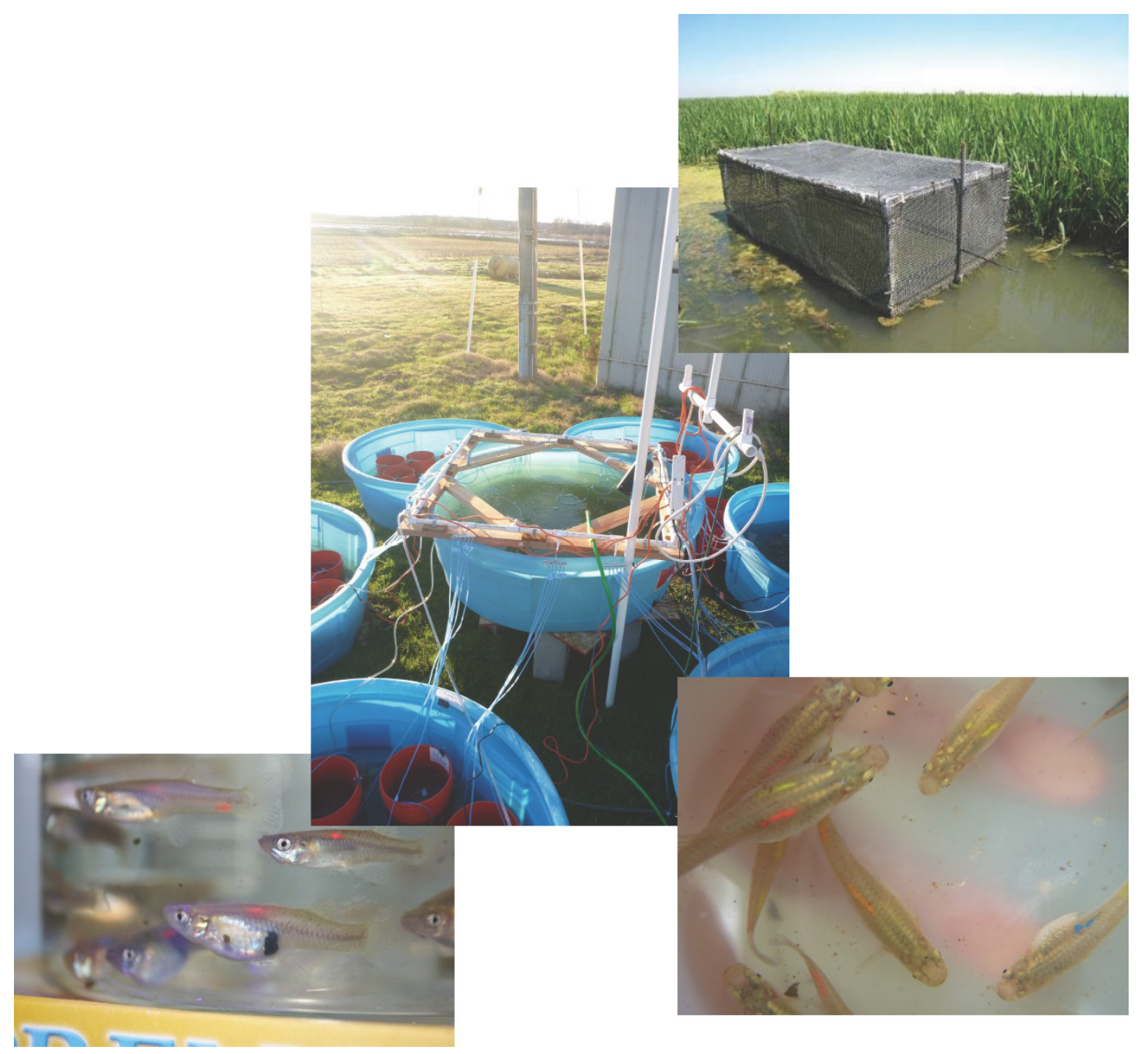

Figure 6. Photographs showing mobile aquaculture and holding pools (center), cage deployed in wetland (upper right), western mosquitofish (Gambusia affinis) with elastomer tags along dorsal fin (bottom left and bottom right).

Each fish was then deployed into the field in a $120 \times 55 \times 55 \mathrm{~cm}(357 \mathrm{~L})$ cage constructed from $3.175 \mathrm{~mm}$ mesh polypropylene aquaculture netting. Cages were placed at the inlet and outlet of each managed wetland ( $\mathrm{N}=9$ wetlands and 18 cages) and rice field ( $\mathrm{N}=9$ rice fields and 18 cages), within the mainstem Cosumnes River upstream and downstream of the treatment areas on the Preserve $(\mathrm{N}=2$ cages), at source water pump locations within the sloughs ( $\mathrm{N}=4$ cages) and interior canals ( $\mathrm{N}=5$ cages), and within some drainage canals ( $\mathrm{N}=3$ cages). In total, we introduced 1,500 mosquitofish during each of the three study time periods for a total of 4,500 fish. For the cages placed at the inlets and outlets of wetlands and rice fields, we excavated approximately $15 \mathrm{~cm}$ of soil at each cage location more than 1 month prior to cage placement to ensure that enough water for fish survival would remain within the cage should a field unintentionally begin to dry due to pump failure or excessive drainage. We held fish in cages under field conditions for 30 days. Upon retrieval, we weighed and measured each fish as described during tagging. We identified each retrieved fish by using the sequencing of the fish tags. Fish were thereafter stored frozen at $-20^{\circ} \mathrm{C}$ until they were processed in the laboratory. 


\section{Water Sampling}

Surface-water samples were collected from mid-water column at the inlets and outlets of nine rice fields and at the primary irrigation supply pump for the rice growing area within the Preserve. Water samples were collected four times per season (approximately every 5 weeks) between June 1 and September 15, 2011 (summer 2011); November 16, 2011 and February 28, 2012 (winter 2011/2012); and June 5, 2012 and September 7, 2012 (summer 2012) in rice fields, but only during summer seasons in wetlands. Inlet-only samples were collected during the first sampling event of each season because fields were often not yet fully inundated to the outlets, and outlet-only samples were collected during the final sampling event of each season because some inlets were beginning to dry out. Samples were collected by immersing a 1 or 2 L clean and sterile polyethylene terephthalate (PETG) bottle in the water column without disturbing the bottom substrate. In some cases, water depth was too shallow to immerse the bottle without disturbance, so the cap was used to fill the bottle using multiple dips and compositing in the bottle. Once the sample was collected, the bottles were capped, double-bagged, and placed on ice in a dark cooler for transport to the laboratory for processing. Ancillary water-quality measurements ( $\mathrm{pH}$, temperature, electrical conductivity [EC], dissolved oxygen) were collected using a field-deployed multisonde, either a YSI 6920 (http://www.ysi.com/productsdetail.php?6920-V2-3) and/or a prototype of a YSI EXO (http://www.exowater.com/exo2) equipped with optical sensors for chlorophyll a, turbidity, and fluorescing dissolved organic matter in addition to the measurements listed above. All surface-water samples were collected during controlled, managed flooding conditions. There was a period of regional flooding during the winter/spring of 2012 that was not measured.

\section{Laboratory Methods}

\section{Fish Processing and Mercury Determination}

Upon return to the laboratory, each fish was thawed to room temperature, rinsed with deionized water, blotted dry, and weighed again on an analytical balance. We then dried each fish to a constant mass at $50{ }^{\circ} \mathrm{C}$ for approximately 48 hours (Ackerman and Eagles-Smith, 2010). After drying, we removed fish from the oven and cooled them to room temperature in a desiccator, and weighed them again on an analytical balance to obtain a dry weight for each individual fish. Samples were then homogenized to a fine powder using stainless steel scissors and mortar and pestle.

We measured total $\mathrm{Hg}(\mathrm{THg})$ concentrations in each caged fish because 94.3 percent of $\mathrm{Hg}$ in mosquitofish tissue is MeHg (Ackerman and Eagles-Smith, 2010). Total Hg concentrations were determined in each fish by thermal decomposition and catalytic conversion, and gold amalgamation, followed by atomic absorption spectroscopy following method 7473 (U.S. Environmental Protection Agency, 2000) on a Milestone DMA-80 Hg analyzer.

\section{Water Mercury Determination and Ancillary Parameters}

Upon arrival at the laboratory, the water samples were logged and organized for splitting into aliquots for each selected analysis. Collection bottles were shaken to homogenize the sample and poured quickly into clean glass bottles for analysis of $\mathrm{MeHg}$ in whole-water. Following the splits for the $\mathrm{Hg}$ analyses, an additional aliquot was poured from each sample into a Teflon ${ }^{\circledR}$ filter-tower loaded with a pre-weighed, pre-combusted 0.3 um glass fiber filter. The filtrate was collected in a clean amber bottle and analyzed for dissolved organic matter (DOM) concentration on a carbon basis (as dissolved organic carbon [DOC]) using the high temperature combustion by method 415.3R1 (U.S. Environmental Protection Agency, 2005). Chloride concentrations in water were determined by ion chromatography. 
MeHg analyses for surface-water samples were performed at the Moss Landing Marine Laboratory in Moss Landing, California. The MeHg concentration was determined using distillation and aqueous phase ethylation followed by gas chromatograph separation, pyrolysis, and detection by cold vapor atomic fluorescence spectrometry (Bloom, 1989; Horvat and others, 1993).

\section{Quality Assurance/Quality Control}

For caged fish, THg analysis, quality-assurance measures included analysis of two certified reference materials (either dogfish muscle tissue [DORM-4; National Research Council of Canada, Ottawa, Canada] or dogfish liver [DOLT-3; National Research Council of Canada, Ottawa, Canada]), two system and method blanks, two continuing calibration verifications, and two duplicates per batch of 30 samples. Recoveries ( \pm standard error) averaged $99.18 \pm 0.48$ percent $(\mathrm{N}=197)$ and $98.47 \pm 0.38$ percent $(\mathrm{N}=293)$ for certified reference materials and calibration checks, respectively. Absolute relative percent difference for all duplicates averaged $2.56 \pm 0.68$ percent. For MeHg in water samples, recoveries averaged 104.5 (range 94.9-114.5) percent $(\mathrm{N}=33)$ for calibration checks, whereas recoveries for DOC averaged 100.3 (range 97.3-103.6) percent.

\section{Statistical Analyses}

We used a series of Analysis of Covariance (ANCOVA) models to test for differences in fish and water $\mathrm{THg}$ and $\mathrm{MeHg}$ concentrations among habitats and treatments, as well as across time. However, because fish $\mathrm{Hg}$ concentrations can be influenced by fish size and growth, we first assessed how fish growth varied by season and with initial fish size, in order to develop the best approach for accounting for those variables in the $\mathrm{Hg}$ models.

\section{Caged Fish Mass Changes}

We used a mixed-effects ANCOVA model to test how the change in fish mass ( $\Delta$ mass) over 30 days from deployment to retrieval varied based on initial mass at introduction (mass-at-tagging) and with season. Fixed effects in the model included season (summer 2011, winter 2011-12, and summer 2012), mass-at-tagging, and a season $\times$ mass-at-tagging interaction. We also included cage identification as a random effect in the model so that individual fish would be nested within their specific cage. This analysis was conducted because variable growth rates can influence fish $\mathrm{Hg}$ concentrations by dilution, and it was important to test whether growth rates varied by fish size in order to better parameterize the models of fish $\mathrm{Hg}$ concentrations.

\section{Habitat Differences in Caged Fish Mercury}

Prior to assessing the potential treatment effects in wetlands and rice fields, we first tested for general differences in fish $\mathrm{Hg}$ concentrations among the different habitats that we sampled across the Preserve. To do this, we included only fish samples from outlet cages in order to integrate field-level changes and minimize source-water influences. We used a mixed-effects ANCOVA model with caged fish THg concentrations as the dependent variable. Fixed effects in the model included season (summer 2011, winter 2011-12, and summer 2012), $\Delta$ mass, mass-at-tagging, and habitat (rice field, managed wetland, sloughs). We did not include rivers in the statistical model because cages were washed out 
during some deployment events, resulting in no river data from those time periods, hence the model would not converge with river habitats included. Instead, for comparative purposes, we report geometric mean caged fish THg concentrations from the time periods when fish were recovered from river sites. Finally, we included the individual cage identification nested within habitat as a random effect in the model.

\section{Treatment Effects-Rice Fields and Wetlands}

To test the effects of wetland water management and post-harvest rice field straw management on caged fish THg concentrations, we used a separate ANCOVA model with fixed effects that included treatment (rice fields: standard harvest, chopped and disked, chopped and baled; wetlands: dual drawdown and flood-up, single drawdown and flood-up, or permanent), season (summer 2011, winter 2011-12, summer 2012), field location (inlet or outlet), $\Delta$ mass, and mass-at-tagging. We also included two-way interactions for treatment $\times$ season, treatment $\times$ field location, field location $\times$ season, and a treatment $\times$ season $\times$ field location three-way interaction. Field identification nested within treatment and cage identification nested within field identification were both included in the model as random effects.

\section{Habitat Effects-Rice Fields and Seasonal Wetlands with Matching Hydrology}

In the next tier of our analysis, we compared caged fish $\mathrm{Hg}$ concentrations from rice fields with those from managed wetlands that had the exact same drawdown and flood-up dates (that is, wetlands with dual [spring and fall] drawdown and flood-up). Thus, all fields in this test were managed identically in terms of hydrology, with the only difference being whether fields were used for growing rice or contained wetland vegetation. For this test, we used an ANCOVA model that contained the following fixed effects: habitat type (rice field or managed wetland), season (summer 2011, winter 2011-12, and summer 2012), $\Delta$ mass, and mass-at-tagging. Random effects included rice field postharvest treatment nested within habitat, field identification nested within habitat, and cage identification nested within field identification.

\section{Treatment Effects on Aqueous Methylmercury Concentrations}

For aqueous MeHg concentrations, we developed a slightly revised version of the fish model to address the unique attributes of water $\mathrm{MeHg}$ data. Fixed effects included treatment (rice fields: chopped, chopped and disked, chopped and baled; wetlands: dual drawdown and flood-up, single drawdown and flood-up, or permanent field location), field location (inlet or outlet), field identification nested within treatment, DOC concentration, day of year, and season (summer 2011, winter 2011-12, summer 2012). We also included field identification $\times$ field location and day of year $\times$ season two-way interactions in order to test whether any differences between inlets and outlets were consistent across fields, and whether temporal trends were consistent among seasons. Because we measured aqueous $\mathrm{MeHg}$ concentrations at several time periods within a season, we included site identification as a random effect to place the analysis within a repeated measures framework.

In order to normalize residuals and ensure homogeneity of variance, all fish and water THg and $\mathrm{MeHg}$ concentrations were log-transformed prior to statistical analyses. Unless otherwise noted, we report our results as back-transformed least-square (LS) means ( \pm standard error). Fish THg concentrations are reported in micrograms per gram on a dry weight $(\mathrm{dw})$ basis and unfiltered aqueous $\mathrm{MeHg}$ concentrations are reported in nanograms per liter. 


\section{Load Estimates}

Net surface water loads were calculated using a hydrologic model developed for rice fields in the nearby Yolo Bypass (Bachand and others, 2014a). In summary, the model relates outflow and inflow concentrations where outflow:inflow ratios were compared for each constituent of concern (COC) with that of the conservative tracers chloride $(\mathrm{Cl})$ and electrical conductivity $(\mathrm{EC})$. Using those data, mass budgets were calculated under two scenarios of flow conditions for a field flooded to $15 \mathrm{~cm}$ depth and known field area-(scenario 1) no outlet flow with variable evaporation to evapotranspiration (E/ET) ratios and (scenario 2) 0-2 cm outflow with E/ET locked at 25 percent for a total of eight possible models for each field. Once the conservative tracer budgets were established, those hydrologic conditions were applied to unfiltered aqueous $\mathrm{MeHg}$ concentrations to determine net source or sink for each season.

Potential evapotranspiration (ETo) data were taken from the nearby Lodi CIMIS station approximately $20 \mathrm{~km}$ south of the Preserve. ET crop coefficients differ throughout the growing season but are close to 1 for the seasonal average, so the cumulative seasonal ETo was used in this seasonally averaged flow model as the estimate of the actual ET. In scenario 2 where flow conditions were allowed to vary to meet ET demand, the division of ETo into E and T was established as 25 percent (E/ET) for summer growing conditions based on the range of E/ET reported in literature for rice (21-32 percent; Bachand and others, 2014a,2014b) and vegetated wetlands (20 percent; Goulden and others, 2007). A value of 90 percent (E/ET) was used in winter because of the absence of vegetation over the flooded field except for minor weeds along the field edge late in the season.

Seasonal averages for $\mathrm{EC}$ and $\mathrm{Cl}$ at the inlets and outlets were used to solve for a tracer balance to determine the relative amount of flow in the surface water and percolation into the soil to meet transpiration demand. General surface-inflow conditions were verified with photo-documentation of inflows in five fields. Inflow rates were calculated using estimated pipe flow and hydraulic head based on water sampling visits to compare with model results. In most cases, at least one modeled scenario was deemed unrealistic because it did not converge on a solution within the model constraints and acceptable tolerances, and thus was removed from further analysis. The remaining scenarios were reported (mean \pm standard deviation). For the varying ET models, results were included when E/ET fell in the range of 5-45percent. For the model where E/ET was held constant and flow varied, results were included if the flow was between -0.1 and $2 \mathrm{~cm}$. MeHg loads were determined using the resulting seasonal average hydrologic flowpath allocations and seasonal average $\mathrm{MeHg}$ concentrations where inflow and outflow concentrations were applied to their respective hydrologic flows, and the seasonal average between inlet and outlet were field-averaged for percolation loads into the soil across the field area. This simplified model was verified using data from Bachand and others (2014b), achieving similar results $(<10$ percent difference in calculated net load) using seasonal averages in the model scenarios. Sensitivity analysis of the model was performed by stepwise variation in model inputs. 


\section{Results}

Across three distinct sampling periods (summer 2011, winter 2011-12, and summer 2012), we measured $\mathrm{Hg}$ concentrations in 2,673 caged fish over 30 day exposure periods at the inlets and outlets of each wetland and rice field, as well as other river, slough, and canal locations within the Preserve. We also collected 307 water samples from rice fields, wetlands, pump locations, and sloughs. Across all sites and dates, THg concentrations in caged mosquitofish after 30days of exposure ranged from 0.055 to $2.30 \mu \mathrm{g} / \mathrm{g} \mathrm{dw}$, and the geometric mean ( \pm standard error) concentration was $0.266( \pm 0.003) \mu \mathrm{g} / \mathrm{g} \mathrm{dw}$. In comparison, $\mathrm{THg}$ concentrations in reference mosquitofish prior to deployment in cages ranged from 0.012 to $0.280 \mu \mathrm{g} / \mathrm{g} \mathrm{dw}$. Geometric mean THg concentrations in reference mosquitofish at deployment were $0.039 \pm 0.012$ (summer 2011), $0.155 \pm 0.038$ (winter 2011-12), and $0.073 \pm 0.015$ (summer 2012). Unfiltered aqueous MeHg ranged over two orders of magnitude from 0.023 to $20.3 \mathrm{ng} / \mathrm{L}$ and the geometric mean \pm standard error concentration was $0.424 \pm 0.029 \mathrm{ng} / \mathrm{L}$.

At deployment, the mean ( \pm standard deviation) standard length of female mosquitofish was $39.1 \pm 3.1 \mathrm{~mm}$ (summer 2011), $27.3 \pm 3.4 \mathrm{~mm}$ (winter 2011-012), and $30.5 \pm 4.0 \mathrm{~mm}$ (summer 2012). Similarly, mean mass-at-tagging was $1.57 \pm 0.41 \mathrm{~g}$ (summer 2011), $0.45 \pm 0.18 \mathrm{~g}$ (winter 2011-12), and $0.81 \pm 0.36 \mathrm{~g}$ (summer 2012). Across all sites and habitats, the difference in caged fish length between retrieval and deployment was $1.4 \pm 2.5 \mathrm{~mm}(3.7 \pm 6.4$ percent $)$ during summer $2011,-0.4 \pm 1.5 \mathrm{~mm}$ ($1.3 \pm 5.5$ percent $)$ during winter $2011-12$, and $3.5 \pm 2.7 \mathrm{~mm}(12.2 \pm 10.0$ percent $)$ during summer 2012. Similarly, $\Delta$ mass was $0.01 \pm 0.46 \mathrm{~g}(2.9 \pm 32.4$ percent $)$ during summer 2011 , $-0.01 \pm 0.05 \mathrm{~g}(-1.5 \pm 13.7$ percent $)$ during winter $2011-12$, and $0.22 \pm 0.32 \mathrm{~g}(38.3 \pm 56.5$ percent $)$ during summer 2012. These are overall average changes and do not account for the influence of sitespecific factors or mass-at-tagging.

\section{Fish Growth}

The $\Delta$ mass from deployment to retrieval differed with mass-at-tagging $\left(\mathrm{F}_{1,2605}=99.5, \mathrm{p}<0.0001\right)$ and season $\left(\mathrm{F}_{1,2616}=404.7, \mathrm{p}<0.0001\right)$, but the season $\times$ mass-at-tagging interaction $\left(\mathrm{F}_{1,2605}=85.7\right.$, $\mathrm{p}<0.0001)$ indicated that the slope of the relationship between mass-at-tagging and $\Delta$ mass differed among seasons. Therefore, we ran two separate models, one for each season. Change in mass was negatively correlated with mass-at-tagging $\left(\mathrm{F}_{1,1511}=419.7, \mathrm{p}<0.0001\right)$ during the summer deployments, but did not vary with mass-at-tagging $\left(\mathrm{F}_{1,1086}=2.93, \mathrm{p}=0.09\right)$ during the winter deployment (fig. 7). For example, the smallest fish exhibited up to a 300 percent increase in mass over the summer deployment time period, with smaller proportional changes in the biggest fish, whereas there was no relationship between proportional $\Delta$ mass and mass-at-tagging during the winter season (fig. 7). Because fish growth rates and fish size can be an important determinant of $\mathrm{Hg}$ bioaccumulation, we included both fish massat-tagging and $\Delta$ mass in all subsequent statistical models in order to control for growth dynamics among individual fishes. 

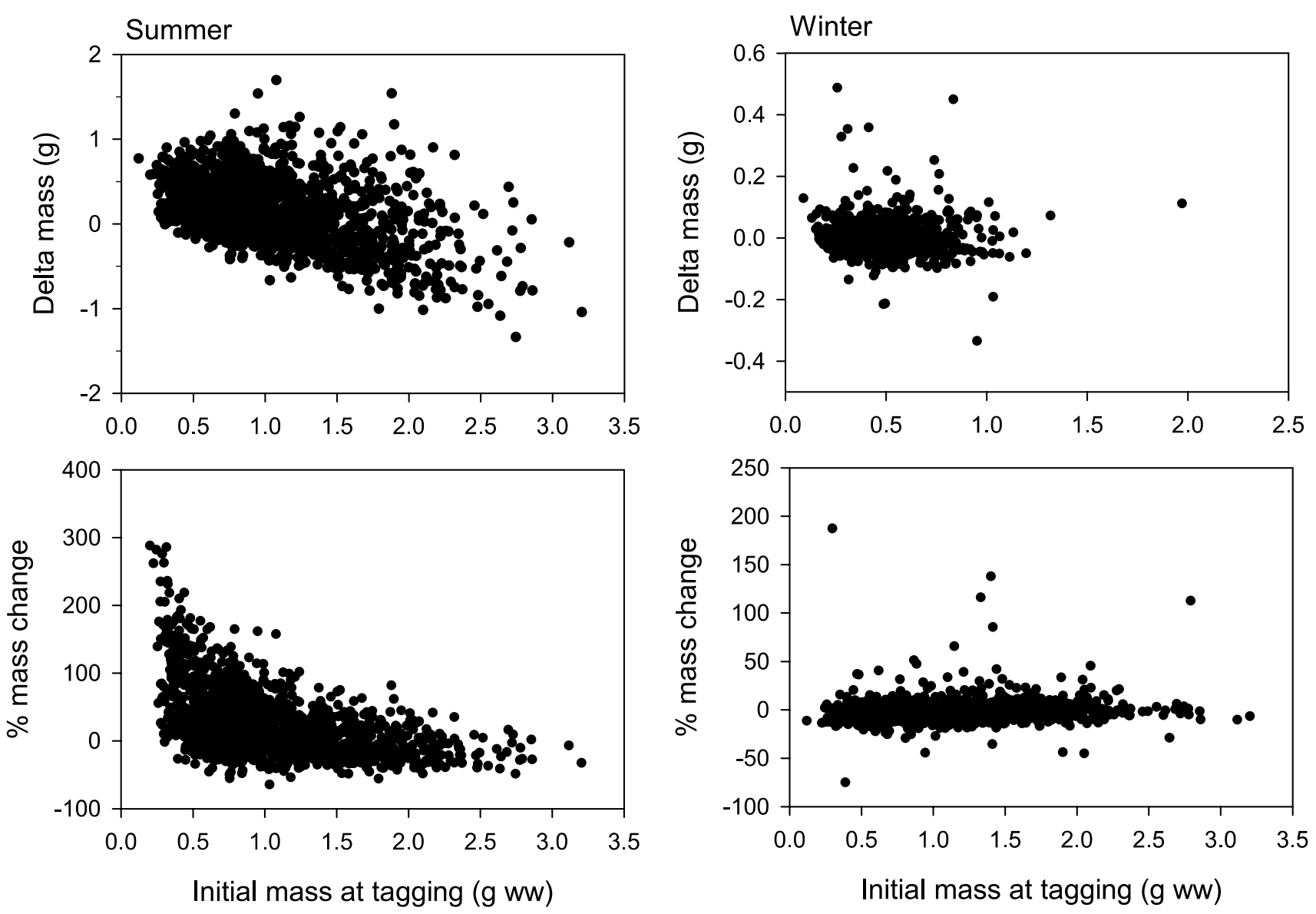

Figure 7. Relationship between change in fish mass ( $\Delta$ mass) and initial fish mass after 30 deployments in cages. Top two panels represent $\Delta$ mass (mass at retrieval - mass at deployment) versus initial fish mass at tagging during the summer (left) and winter (right) deployment time periods. The bottom two panels represent the proportional $\Delta$ mass versus initial fish mass at tagging.

\section{Habitat Differences}

We first compared caged fish THg concentrations among each of the primary habitats (rice fields, managed wetlands, and sloughs) regardless of the water or harvest management treatments, in order to test for inherent habitat differences in fish THg bioaccumulation among habitat types. We could not statistically compare these habitats to the river because we did not have caged fish from riverine sites during each season, thus the model would not converge. Instead, we compared the model-adjusted least-square mean values from each habitat with the geometric mean concentration from caged fish during the time periods where we were able to retrieve caged fish.

Total $\mathrm{Hg}$ concentrations in mosquitofish held in cages for 30 days differed among habitat types $\left(\mathrm{F}_{2,27.39}=11.34, \mathrm{p}=0.0003\right)$ and between seasons $\left(\mathrm{F}_{2,1553}=285.4, \mathrm{p}<0.0001\right)$. However, the significant habitat $\times$ season interaction $\left(\mathrm{F}_{4,1552}=49.59, \mathrm{p}<0.0001\right)$ confounded interpretation of the main effects. Therefore, we used conditional F-tests (slices) to compare caged fish THg concentrations by habitat, separately for each season. Total $\mathrm{Hg}$ concentrations were $2.5 \times$ and $1.9 \times$ higher in caged fish from rice field outlets than in those from outlets of managed wetlands during summer $2011\left(\mathrm{~F}_{2,32.85}=21.24\right.$, 
$\mathrm{P}<0.0001)$ and summer $2012\left(\mathrm{~F}_{2,29.38}=12.81, \mathrm{p}<0.0001\right)$, respectively (fig. 8). Similarly, THg concentrations were $1.8 \times$ higher in caged fish from rice fields than in those from slough habitats in summer 2011 and summer 2012 (fig. 8). Conversely, THg concentrations in caged fish from rice fields did not differ from those in managed wetlands during the winter season, and were only $1.4 \times$ higher than in those from sloughs (fig. 8). Moreover, THg concentrations from caged fish at the outlets of managed wetlands were not different from those in slough habitats during summer 2011, summer 2012, or the winter season (fig. 8). Caged fish $\mathrm{THg}$ concentrations were $3.4 \times$ to $15 \times$ higher upon retrieval than initial $\mathrm{THg}$ concentrations at deployment during the summer season, whereas increases in caged fish $\mathrm{THg}$ concentrations were minimal during the winter season $(1.4 \times$ higher; fig. 8$)$.

\section{Wetlands}

\section{Caged Fish Total Mercury}

Caged fish THg concentrations differed among wetland management treatments $\left(\mathrm{F}_{2,6.12}=7.47\right.$, $\mathrm{p}=0.02)$, between seasons $\left(\mathrm{F}_{2,1007}=252.4, \mathrm{p}<0.0001\right)$, and between field locations $\left(\mathrm{F}_{1,6.05}=9.91, \mathrm{p}<0.02\right)$. Additionally, fish THg concentrations increased with greater $\Delta$ mass $\left(\mathrm{F}_{1,1008}=4.94, \mathrm{p}=0.03\right)$, and decreased with initial fish mass-at-tagging $\left(\mathrm{F}_{1,1005}=5.35, \mathrm{p}=0.02\right)$. We found significant treatment $x$ season $\left(\mathrm{F}_{4,1007}=48.34, \mathrm{p}<0.0001\right)$, treatment $\times$ field location $\left(\mathrm{F}_{2,6.06}=8.26, \mathrm{p}=0.02\right)$, and field location $\times$ season $\left(\mathrm{F}_{2,1007}=60.93, \mathrm{p}<0.0001\right)$ two-way interactions, as well as a season $\times$ treatment $\times$ field location $\left(\mathrm{F}_{4,1007}=35.4, \mathrm{p}<0.0001\right)$ three-way interaction.

The significant interaction terms confounded the interpretation of main effects; therefore, we used conditional F-tests to assess the influence of treatment by site and season. Caged fish $\mathrm{THg}$ concentrations varied from inlets to outlets and among seasons differently for each treatment (fig. 9). In permanent wetlands, there were no differences in fish $\mathrm{THg}$ concentrations between inlets and outlets during summer $2011(\mathrm{t}=0.77, \mathrm{p}=0.47)$ or winter 2011-12 $(\mathrm{t}=0.28, \mathrm{p}=0.79)$. However, caged fish $\mathrm{THg}$ concentrations increased from inlets to outlets in permanent wetlands during summer 2012 by $1.45 \times$ (from 0.195 to $0.283 \mu \mathrm{g} / \mathrm{g} \mathrm{dw} ; \mathrm{t}=2.75, \mathrm{p}=0.03$; fig. 9). In single (fall only) drawdown and flood-up and dual (fall and spring) drawdown and flood-up seasonal wetlands, caged fish THg concentrations decreased from inlets to outlets during summer 2011 and summer 2012 (fig. 9). However, caged fish $\mathrm{THg}$ concentrations did not change from inlets to outlets in either seasonal wetland treatment during the winter deployment event (fig. 9).

Among treatments, THg concentrations in caged fish from inlets did not differ between the two seasonal wetland treatments during any of the three deployment time periods. In contrast, caged fish from the inlets of permanent wetlands were consistently lower than those from the inlets of both seasonal wetland treatments during the two summer deployments (fig. 9). There were no differences among any treatments or locations during the winter deployment. Fish $\mathrm{THg}$ concentrations at the outlets only differed among treatments during summer 2011 when caged fish from dual (fall and spring) drawdown and flood-up wetland outlets were higher than in those from both single (fall only) drawdown and flood-up wetlands and permanent wetlands (fig. 9).

\section{Aqueous Methylmercury}

Aqueous $\mathrm{MeHg}$ concentrations within managed wetlands were highly variable (fig. 10), and a significant interaction between treatment and field locations $\left(F_{2,87.2}=6.25, p=0.003\right)$ confounded our ability to examine the main effects of either treatment or field location alone. Therefore, we conducted separate analyses for each treatment type. 

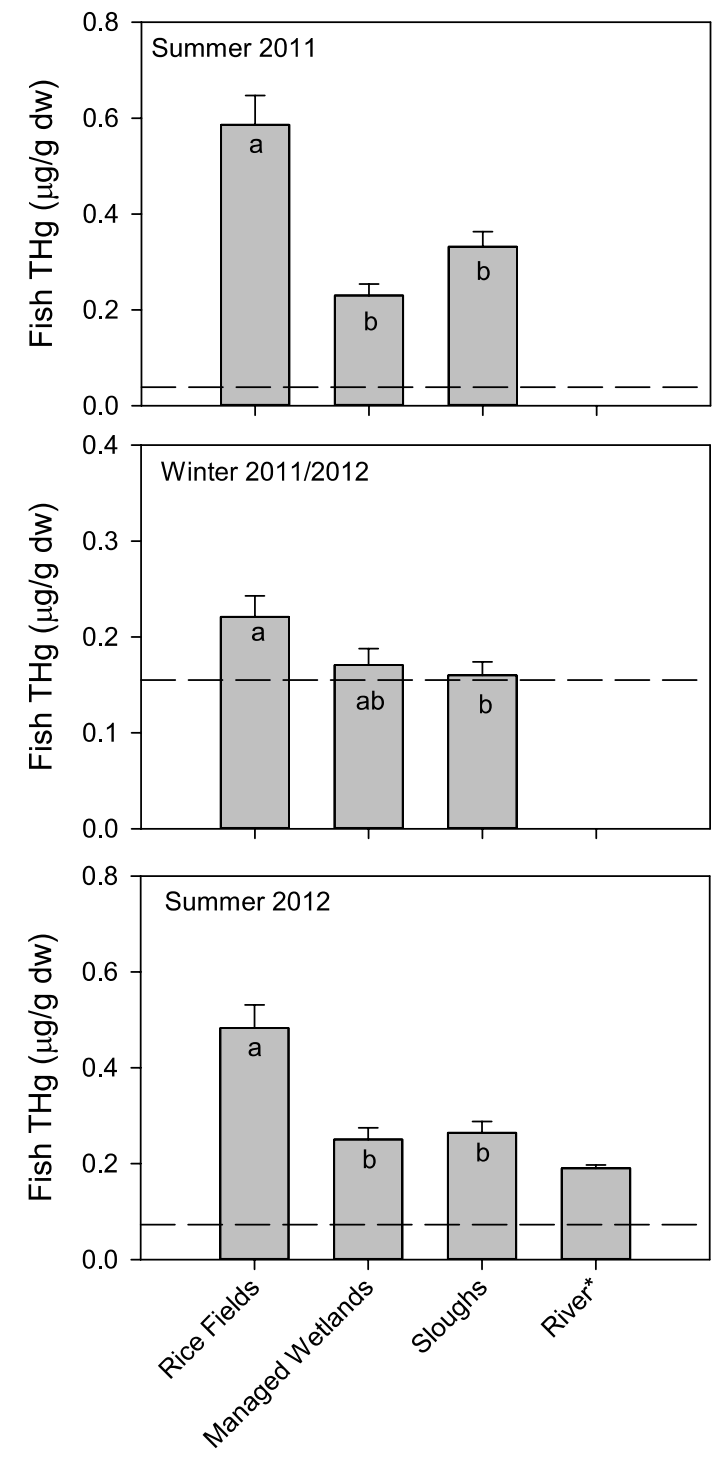

Figure 8. Caged fish total mercury (THg) concentrations (least-square mean \pm standard error) across habitats in the Cosumnes River Preserve after 30 days of deployment. Least-square mean concentrations statistically controlled for the effects of site, fish size, and fish growth. ${ }^{*}$ Caged fish THg concentration from river sites are included as geometric means because the unbalanced temporal sampled precluded model convergence with river sites included in the model. Different letters within seasons indicate $p<0.05$. Dashed lines indicate initial fish $\mathrm{THg}$ concentration at deployment. 

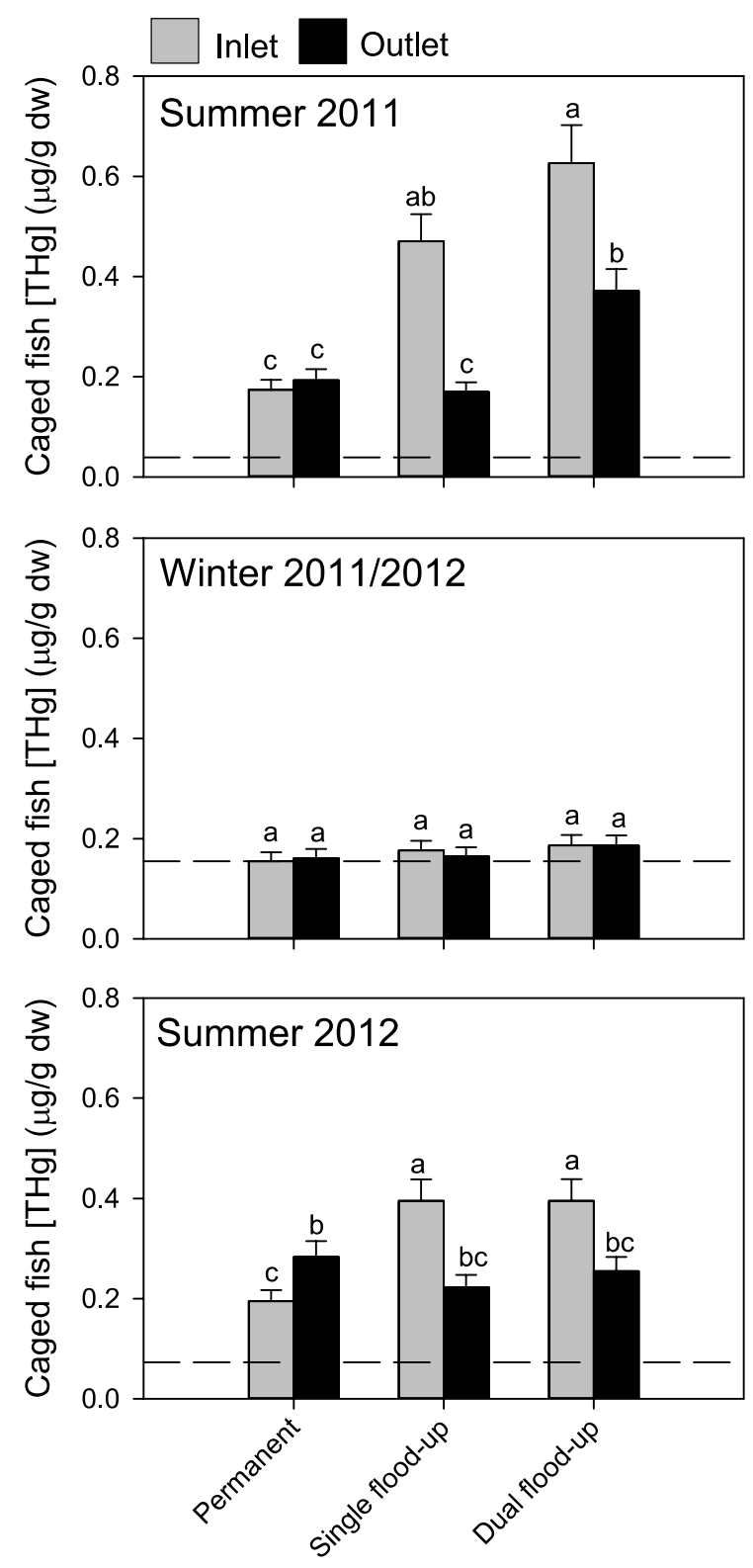

Managed Wetland Treatment

Figure 9. Total mercury ( $\mathrm{THg}$ ) concentrations (least-square mean \pm standard error) from caged fish placed at the inlets (gray bars) and outlets (black bars) of permanently inundated, single (fall-only) drawdown and flood-up, and dual (fall and spring) drawdown and flood-up managed wetlands in the Cosumnes River Preserve during summer 2011, winter 2011-12, and summer 2012. Different letters indicate significant differences $(p<0.05)$ based on conditional F-tests Dashed lines represent reference fish THg concentrations at deployment. 

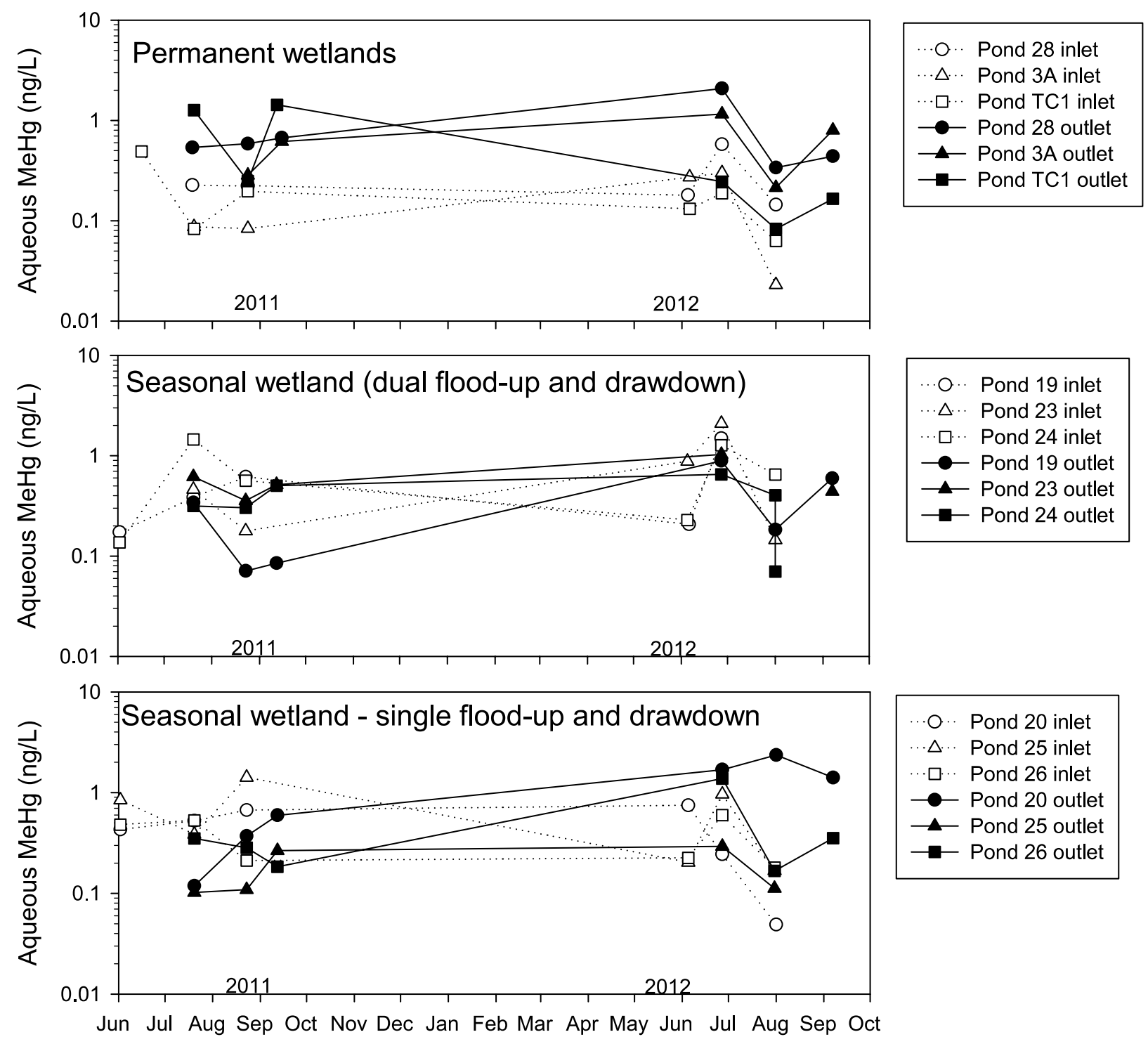

\section{Sampling Date}

Figure 10. Temporal variation in unfiltered aqueous methylmercury $(\mathrm{MeHg})$ concentrations (ng/L) from managed wetlands in the Cosumnes River Preserve between June 2011 and September 2012. 


\section{Dual (Fall and Spring) Drawdown and Flood-Up Seasonal Wetlands}

Unfiltered aqueous MeHg concentrations in dual (fall and spring) drawdown and flood-up seasonal wetlands differed between inlets and outlets $\left(\mathrm{F}_{1,23}=6.77, \mathrm{p}=0.002\right)$, but not among fields $\left(\mathrm{F}_{2,23}=5.97, \mathrm{p}=0.07\right)$. However, the significant interaction between location (inlets and outlets) and fields $\left(\mathrm{F}_{2,23}=4.82, \mathrm{p}=0.03\right)$ indicates that there were different relationships between inlet and outlet unfiltered aqueous $\mathrm{MeHg}$ concentrations among fields. Indeed, $\mathrm{MeHg}$ concentrations decreased substantially from inlets to outlets in Ponds 19 and 24, whereas there was little change from inlets to outlets in Pond 23 (fig. 11a). We also found a significant interaction between days-post-flooding and sampling year $\left(\mathrm{F}_{1,23}=5.53, \mathrm{p}=0.03\right)$, suggesting that temporal trends in aqueous $\mathrm{MeHg}$ concentrations differed between years. Specifically, when statistically accounting for the other factors in the model, modeled aqueous $\mathrm{MeHg}$ concentrations increased over time in 2011, but did not change with time in 2012. Aqueous $\mathrm{MeHg}$ concentrations also increased with increasing DOC concentrations $\left(\mathrm{F}_{1,23}=5.26, \mathrm{p}=0.007\right.$; fig. 12).

\section{Single (Fall Only) Drawdown and Flood-Up Seasonal Wetlands}

Unlike the dual (fall and spring) drawdown and flood-up seasonal wetlands, we found no difference among fields $\left(F_{2,23}=0.82, p=0.45\right)$, nor between inlets and outlets $\left(F_{1,23}=0.02, p=0.88\right)$. We also did not find any significant interaction effects between field location (inlet versus outlet) and field $\left(F_{2,23}=1.68, p=0.21\right.$; fig. $\left.11 b\right)$. Similarly, there were no day-of year effects $\left(F_{1,23}=0.81, p=0.38\right)$, between year effects $\left(\mathrm{F}_{1,23}=0.02, \mathrm{p}=0.90\right)$, nor any relationship between $\mathrm{DOC}$ and aqueous $\mathrm{MeHg}$ concentrations $\left(\mathrm{F}_{1,23}=0.01, \mathrm{p}=0.91\right)$.

\section{Permanently Flooded Wetlands}

In permanently flooded managed wetlands, aqueous $\mathrm{MeHg}$ concentrations were higher in outlets than in inlets $\left(\mathrm{F}_{1,23}=8.55, \mathrm{p}=0.007\right.$; fig. $\left.11 \mathrm{c}\right)$, and differed among fields $\left(\mathrm{F}_{2,23}=5.46, \mathrm{p}=0.01\right)$. Additionally, aqueous $\mathrm{MeHg}$ concentrations were higher in $2011(0.375 \pm 0.072 \mathrm{ng} / \mathrm{L})$ than in 2012 $\left(0.197 \pm 0.032 \mathrm{ng} / \mathrm{L} ; \mathrm{F}_{1,23}=6.40, \mathrm{p}=0.02\right)$, decreased with day-of-year $\left(\mathrm{F}_{1,27}=4.92, \mathrm{p}=0.03\right.$; fig. 13), and increased with DOC concentrations $\left(\mathrm{F}_{1,27}=14.39, \mathrm{p}=0.0008\right.$; fig. 14).

\section{Rice Fields}

\section{Caged Fish Total Mercury}

Caged fish $\mathrm{THg}$ concentrations in rice fields were positively correlated with $\Delta$ mass $\left(\mathrm{F}_{1,1088}=5.14, \mathrm{p}=0.02\right)$ and negatively correlated with mass-at-tagging $\left(\mathrm{F}_{1,1083}=7.011, \mathrm{p}=0.01\right)$. However, the significant treatment $\times$ season interaction $\left(\mathrm{F}_{4,1084}=17.74, \mathrm{p}<0.0001\right)$ and field location $\times$ treatment $\times$ season interaction $\left(\mathrm{F}_{4,1084}=10.54, \mathrm{p}<0.0001\right)$ confounded direct interpretation of main effects. Therefore, we used conditional F-tests to compare fish $\mathrm{THg}$ concentrations separately among treatments, field locations (inlets and outlets), and seasons.

Caged fish THg concentrations did not differ from inlets to outlets for standard harvest (chopped only) rice fields during any of the deployment events $(t=-0.717, p=0.49$; fig. 15), nor were there any differences from inlets to outlets for any treatments during the winter season (all $\mathrm{p}>0.10$ ). However, caged fish $\mathrm{THg}$ concentrations increased from inlets to outlets in chopped and baled fields during summer $2011(\mathrm{t}=5.43, \mathrm{p}=0.002)$ and summer $2012(\mathrm{t}=2.41, \mathrm{P}=0.03)$, as well as in chopped and disked fields in summer 2012, but not summer 2011 (fig. 15). 

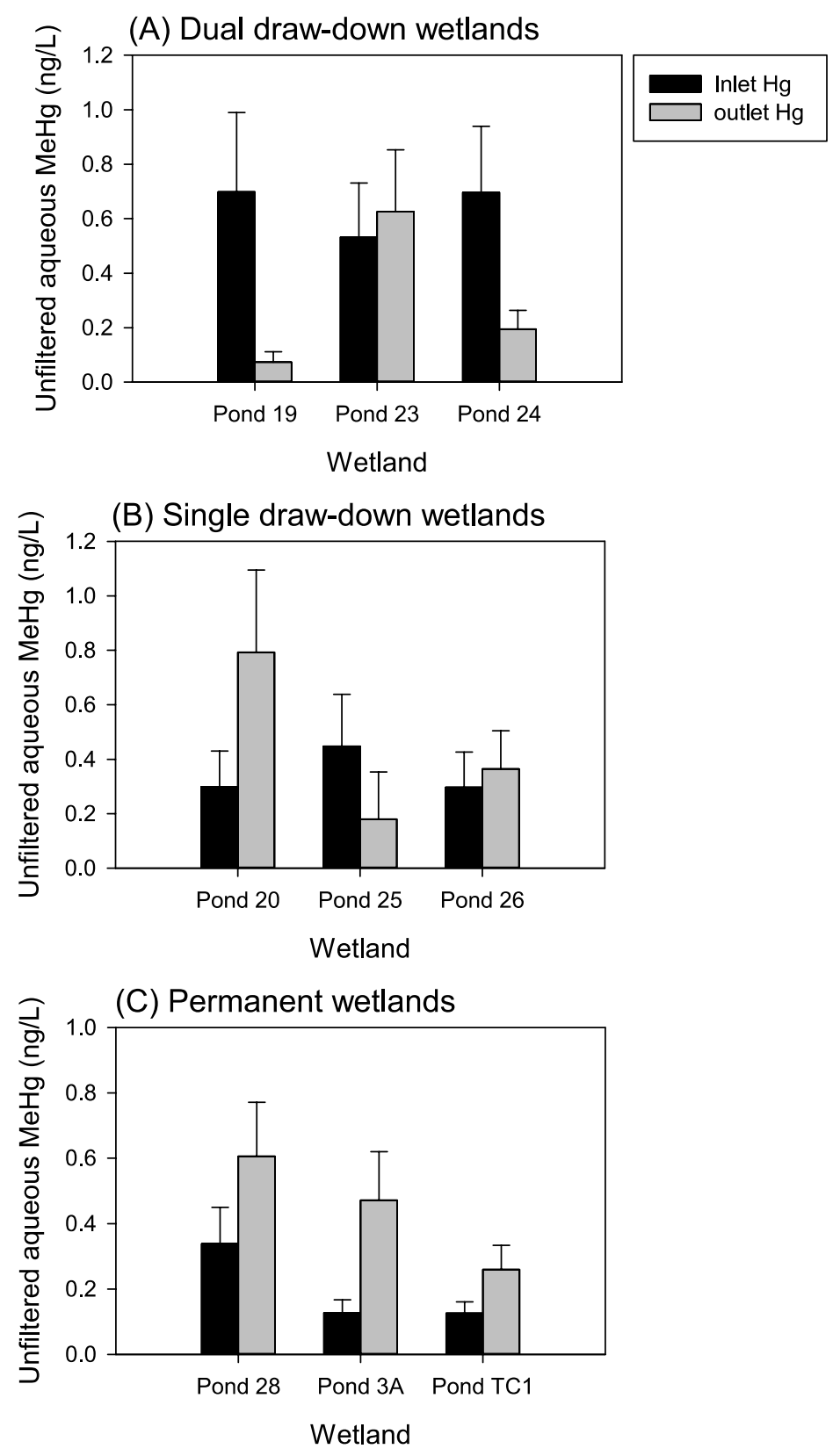

Figure 11. Aqueous methylmercury (MeHg) concentrations (unfiltered, $\mathrm{ng} / \mathrm{L}$ ) in inlets (black bars) and outlets (gray bars) of (A) dual drawdown seasonal wetlands, (B) single drawdown seasonal wetlands, and (C) permanent wetlands in the Cosumnes River Preserve. Concentrations are reported as least-square means (whiskers = standard error) from an analysis of covariance model controlling for the effects of dissolved organic carbon, season, and date. 


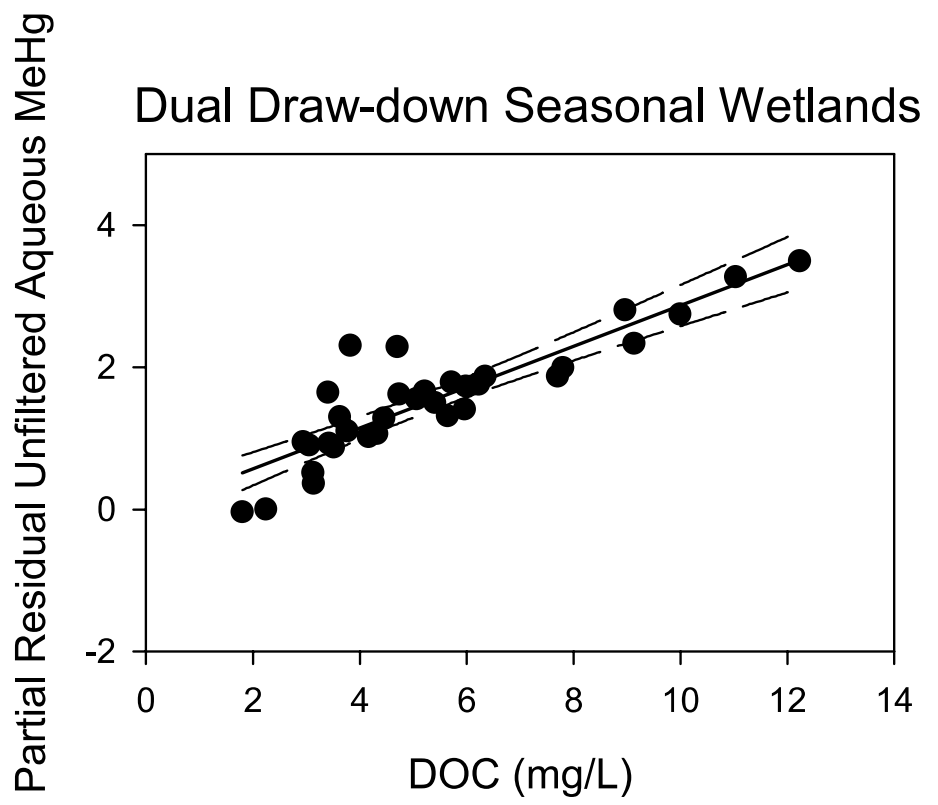

Figure 12. Relationship between aqueous methylmercury ( $\mathrm{MeHg}$ ) concentrations ( $\mathrm{ng} / \mathrm{L}$ unfiltered) and dissolved organic carbon (DOC) concentrations in dual drawdown seasonal wetlands in the Cosumnes River Preserve. Aqueous MeHg concentrations are reported as partial residuals from the ANCOVA model that controlled for site, season, and date effects.

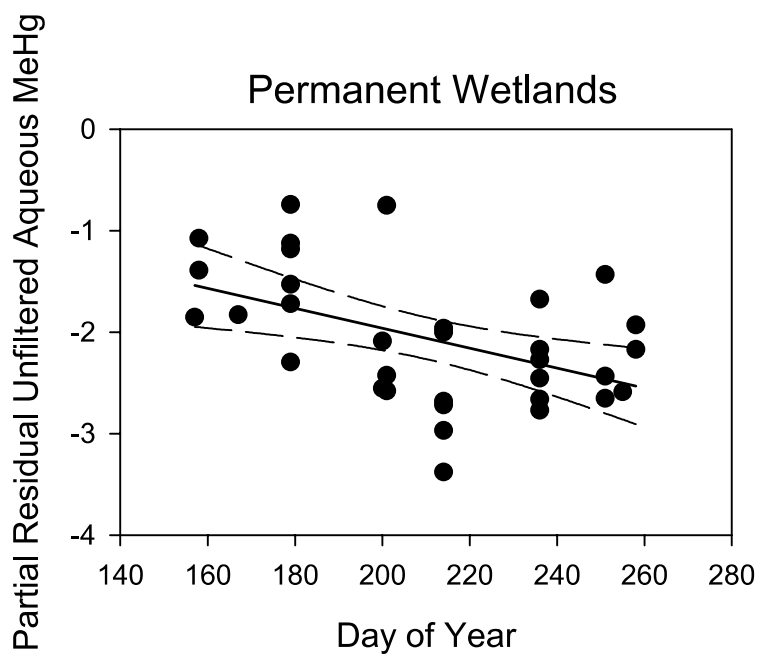

Figure 13. Relationship between aqueous methylmercury (MeHg) concentrations (ng/L unfiltered) and day-of-year in permanent wetlands in the Cosumnes River Preserve. Aqueous MeHg concentrations are reported as partial residuals from the ANCOVA model controlling for site, date, season, and dissolved organic carbon effects. 


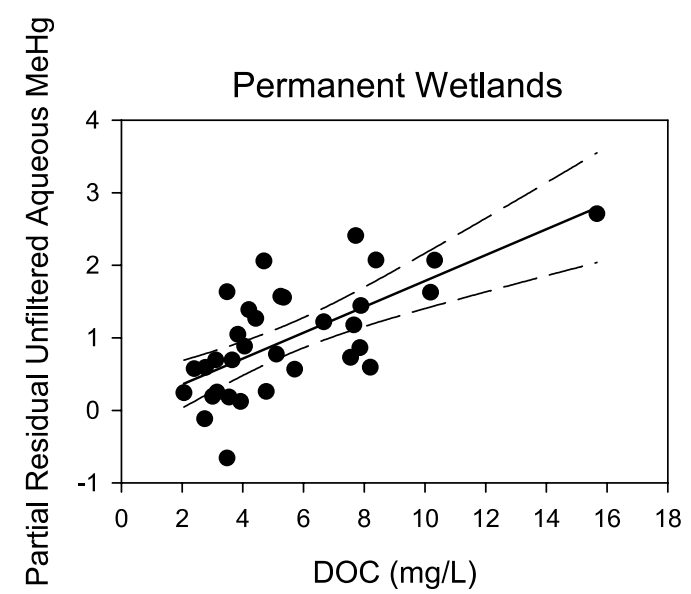

Figure 14. Relationship between aqueous methylmercury ( $\mathrm{MeHg}$ ) concentrations ( $\mathrm{ng} / \mathrm{L}$ unfiltered) and dissolved organic carbon (DOC) concentrations in permanent wetlands in the Cosumnes River Preserve. Aqueous $\mathrm{MeHg}$ concentrations are reported as partial residuals from the ANCOVA model controlling for site, date, and season, effects.

Among treatments, inlet caged fish THg concentrations did not differ during any time period (all $\mathrm{p}>0.05$; fig. 15). At the outlets, caged fish $\mathrm{THg}$ concentrations were higher in chopped and baled fields and both standard harvest (chopped only; $\mathrm{t}=-4.105, \mathrm{p}=0.002)$, and chopped and disked $(\mathrm{t}=-2.47, \mathrm{p}=0.03$ ) fields during summer 2000, whereas Hg concentrations were only higher in caged fish from outlets of chopped and baled fields than in fish from standard harvest fields, but not chopped and disked fields in 2012 (fig. 15). Moreover, caged fish THg concentrations were higher in disked fields than in standard harvest fields during summer 2012, but not during summer 2011 (fig. 15). There were no differences at outlets among treatments during the winter deployment (all $\mathrm{p}>0.05$ ). 

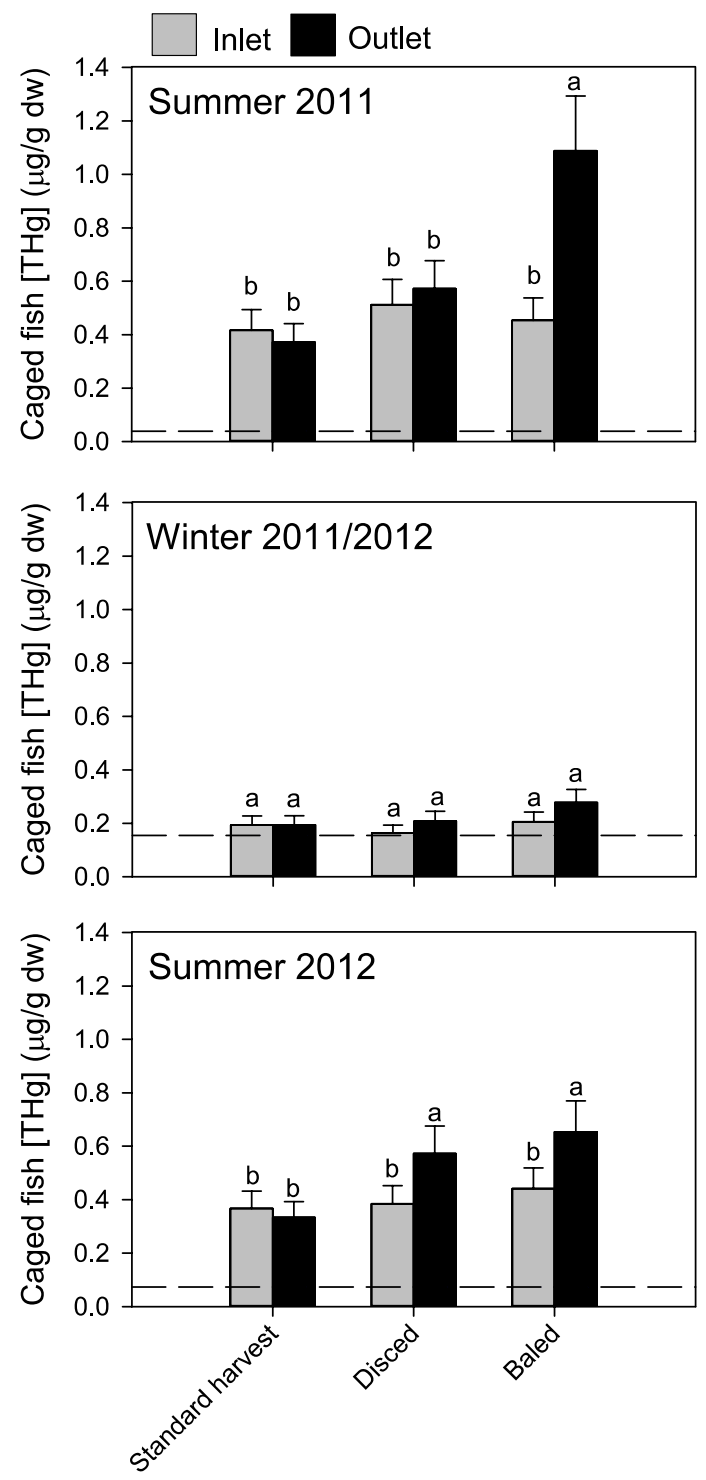

Rice Post-Harvest Treatment

Figure 15. Total mercury (THg) concentrations (least squared mean \pm standard error) from caged fish placed at the inlets (gray bars) and outlets (black bars) of rice fields subjected to one of three post-harvest straw management treatments in the Cosumnes River Preserve during summer 2011, winter 2011-12, and summer 2012. Different letters indicate significant differences $(p<0.05)$ based upon conditional F-tests. Dashed lines represent reference fish $\mathrm{THg}$ concentrations at deployment. 


\section{Aqueous Methylmercury}

As in the managed wetlands, aqueous $\mathrm{MeHg}$ concentrations were highly variable (fig. 16). However, unlike with fish, we did not find any differences in aqueous $\mathrm{MeHg}$ concentrations among post-harvest rice treatments $\left(\mathrm{F}_{2,6.01}=0.53, \mathrm{p}=0.62\right)$, nor did inlet and outlet $\mathrm{MeHg}$ concentrations differ across treatments $\left(\mathrm{F}_{1,142.4}=2.68, \mathrm{p}=0.10\right)$. We did find within-season $\left(\mathrm{F}_{1,142.2}=29.03, \mathrm{p}<0.0001\right)$, betweenseason $\left(\mathrm{F}_{1,142.2}=11.92, \mathrm{p}=0.0007\right)$, and between-year $\left(\mathrm{F}_{1,142.1}=6.11, \mathrm{p}=0.01\right)$ differences in aqueous $\mathrm{MeHg}$ concentrations in rice fields. However, a significant days-post-flood-up $\times$ season interaction $\left(\mathrm{F}_{1,142.1}=29.02, \mathrm{p}<0.0001\right)$ indicated that $\mathrm{MeHg}$ concentrations changed with time differently between summer and winter sampling time periods. In fact, aqueous $\mathrm{MeHg}$ concentrations decreased with date during the summer sampling periods, but did not change over time in the winter (fig. 17). Overall, $\mathrm{MeHg}$ concentrations in unfiltered water were higher in the winter than in the summer (fig. 18), and increased with increasing DOC concentrations $\left(\mathrm{F}_{1,143}=25.76, \mathrm{p}<0.0001\right.$; fig. 19).

\section{Dissolved Organic Carbon}

Unlike with aqueous $\mathrm{MeHg}$ concentrations, DOC concentrations differed among rice treatments $\left(\mathrm{F}_{2,6.02}=8.00, \mathrm{p}=0.02\right)$. DOC concentrations were highest in the standard harvest (chopped only) treatment and lowest in the chopped and baled treatment; the chopped and disked treatment did not differ from standard harvest or chopped and baled treatments. DOC concentrations were substantially higher at the field outlets than at the inlets $\left(F_{1,144.2}=96.65, p<0.0001\right.$; fig. 20). The largest increases from inlets to outlets occurred during summer 2012, but this was largely because inlet DOC concentrations were much lower in the summer than in the winter and outlet concentrations were not substantially different from one another among seasons (fig. 20). Finally, DOC concentrations (mg/L) were higher in the winter $(6.61 \pm 0.14)$ than in the summer $\left(4.29 \pm 0.14 ; \mathrm{F}_{1,144.2}=53.18, \mathrm{p}<0.0001\right)$, but did not vary over time within seasons $\left(\mathrm{F}_{1,144.3}=0.98, \mathrm{p}=0.32\right)$.

\section{Habitat Effects-Rice Fields and Seasonal Wetlands with Matching Hydrology}

In addition to comparing differences in caged fish $\mathrm{THg}$ concentrations among wetland and rice field treatments, we also compared caged fish $\mathrm{THg}$ concentrations between rice fields and dual (fall and spring) drawdown and flood-up seasonal wetlands that were subjected to identical hydrologic patterns. Thus, we assessed whether processes other than wetting and drying patterns within these two habitat types influenced $\mathrm{Hg}$ bioaccumulation. The significant season $\times$ habitat $\left(\mathrm{F}_{2,1440}=22.78, \mathrm{p}<0.0001\right)$, field location $\times$ habitat $\left(\mathrm{F}_{1,10.29}=8.94, \mathrm{p}=0.01\right)$, field location $\times$ season $\left(\mathrm{F}_{2,1440}=18.27, \mathrm{p}<0.0001\right)$, and habitat $\times$ field location $\times$ season $\left(F_{2,1440}=25.77, p<0.0001\right)$ interactions confounded the interpretations of main effects; therefore, we used conditional F-tests to compare $\mathrm{Hg}$ concentrations separately by habitat, season, and field location.

Total $\mathrm{Hg}$ concentrations in rice field caged fish increased from inlets to outlets in summer 2011 $(\mathrm{t}=2.52, \mathrm{p}=0.02)$ and summer $2012(\mathrm{t}=2.31, \mathrm{p}=0.04$; fig. 21), whereas we found an opposite pattern where $\mathrm{THg}$ concentrations in fish decreased from inlets to outlets in seasonal wetlands with the exact same hydrologic fluctuations (summer 2011: $\mathrm{t}=-3.07, \mathrm{p}=0.008$; summer 2012: $\mathrm{t}=-5.446, \mathrm{p}=0.0001$; fig. 21). Correspondingly, during the summer time periods, caged fish $\mathrm{THg}$ concentrations were higher from the inlets of seasonal wetlands than from the inlets of rice fields, whereas caged fish $\mathrm{THg}$ concentrations were higher from the outlets of rice fields than from the outlets of seasonal wetlands (fig. 21). There were no differences between inlets and outlets during the winter deployment for either rice fields $(\mathrm{t}=2.02, \mathrm{p}=0.07)$ nor seasonal wetlands $(\mathrm{t}=0.04, \mathrm{p}=0.97$; fig. 21$)$. 

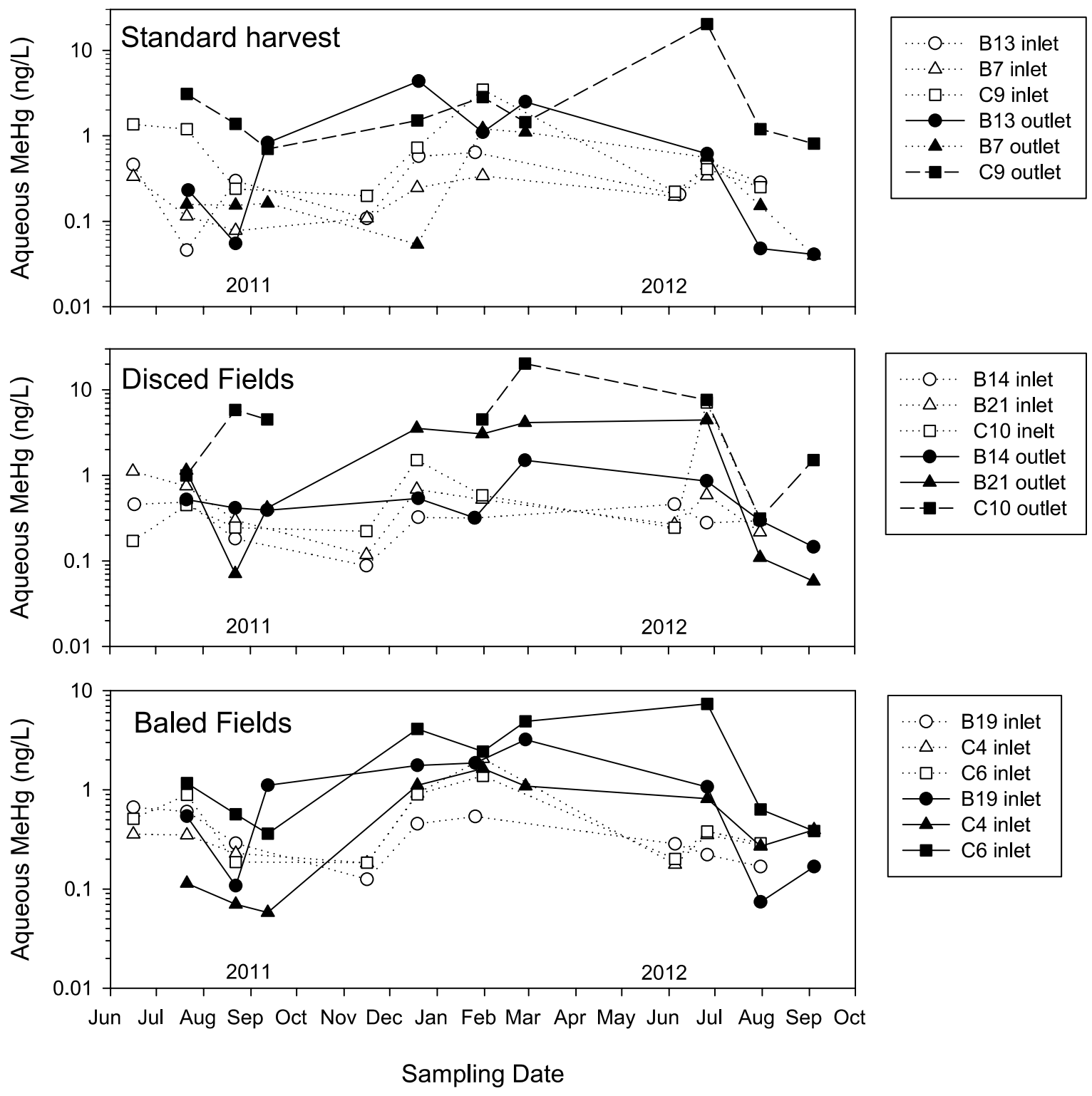

Figure 16. Temporal variation in unfiltered aqueous methylmercury $(\mathrm{MeHg})$ concentrations $(\mathrm{ng} / \mathrm{L})$ from rice fields in the Cosumnes River Preserve between June 2011 and September 2012. 

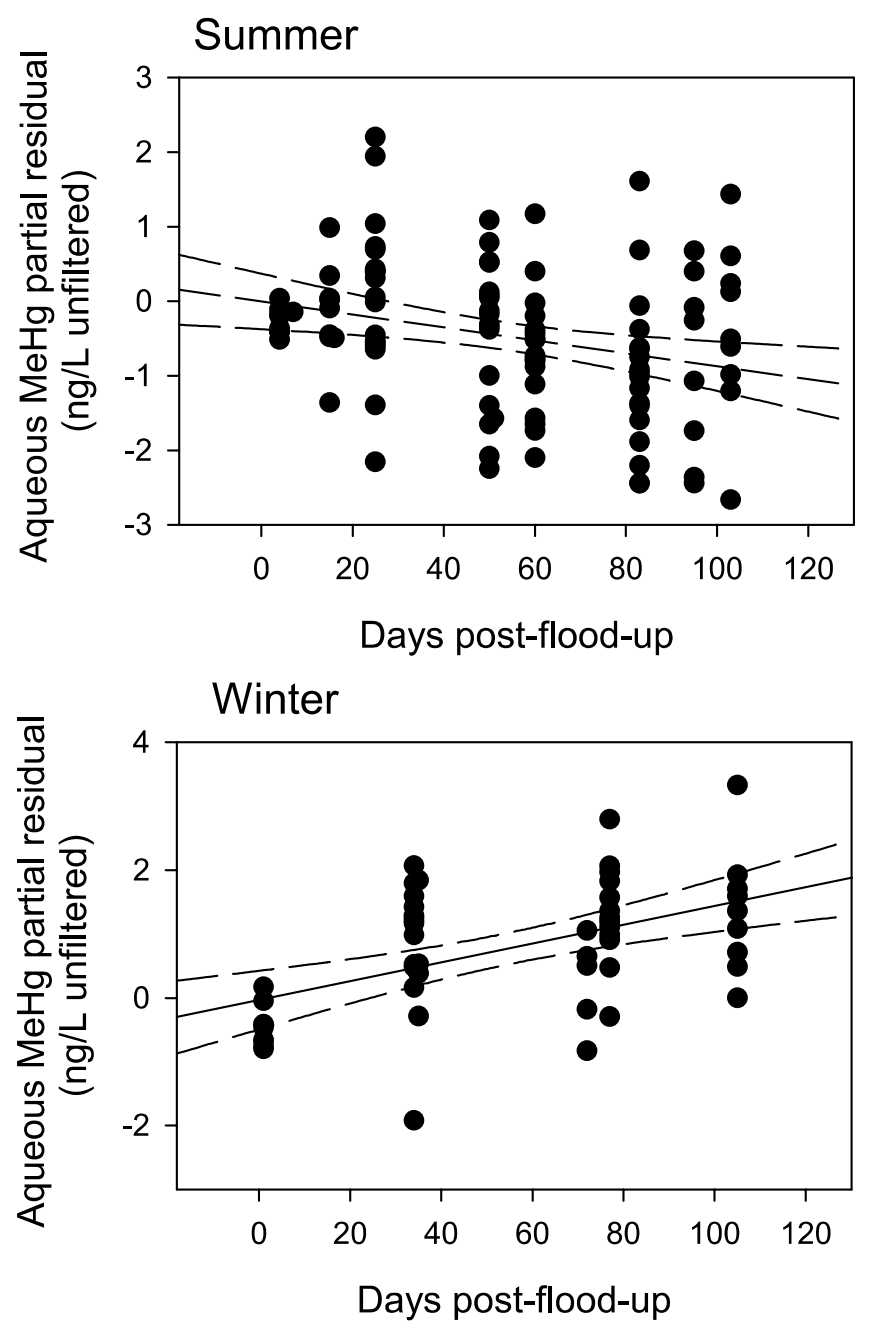

Figure 17. Aqueous methylmercury (MeHg) concentrations in rice fields versus days post flood-up in summer (top panel) and winter (bottom panel) in the Cosumnes River Preserve. Methylmercury concentrations are reported as partial residuals from the ANCOVA model accounting for site, dissolved organic carbon, year, and treatment effects. 


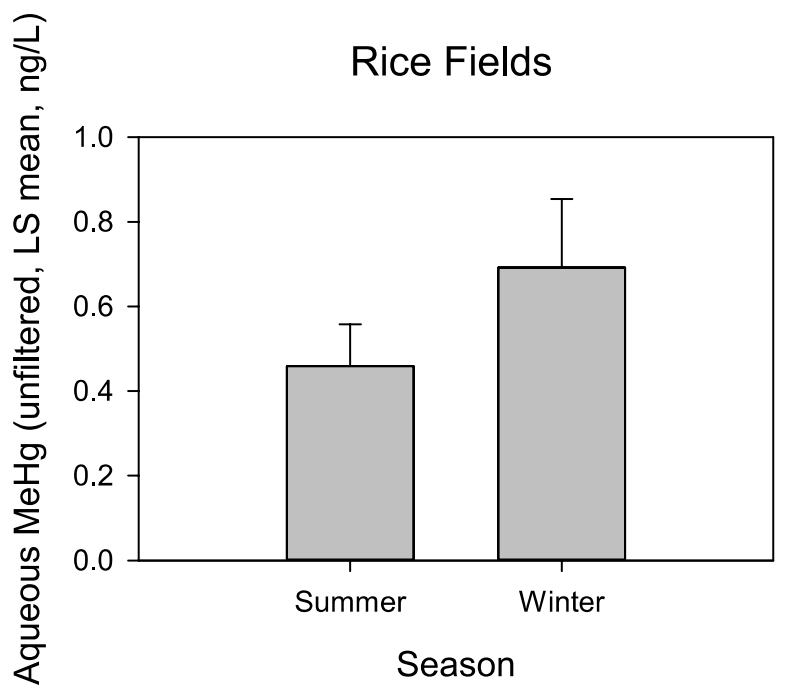

Figure 18. Seasonal differences in aqueous methylmercury (MeHg) concentrations (unfiltered, $\mathrm{ng} / \mathrm{L}$ ) in rice fields in the Cosumnes River Preserve. Values represent least-square mean (bar height) and standard errors (whiskers) from the ANCOVA model controlling for treatment, site, time, and dissolved organic carbon effects.

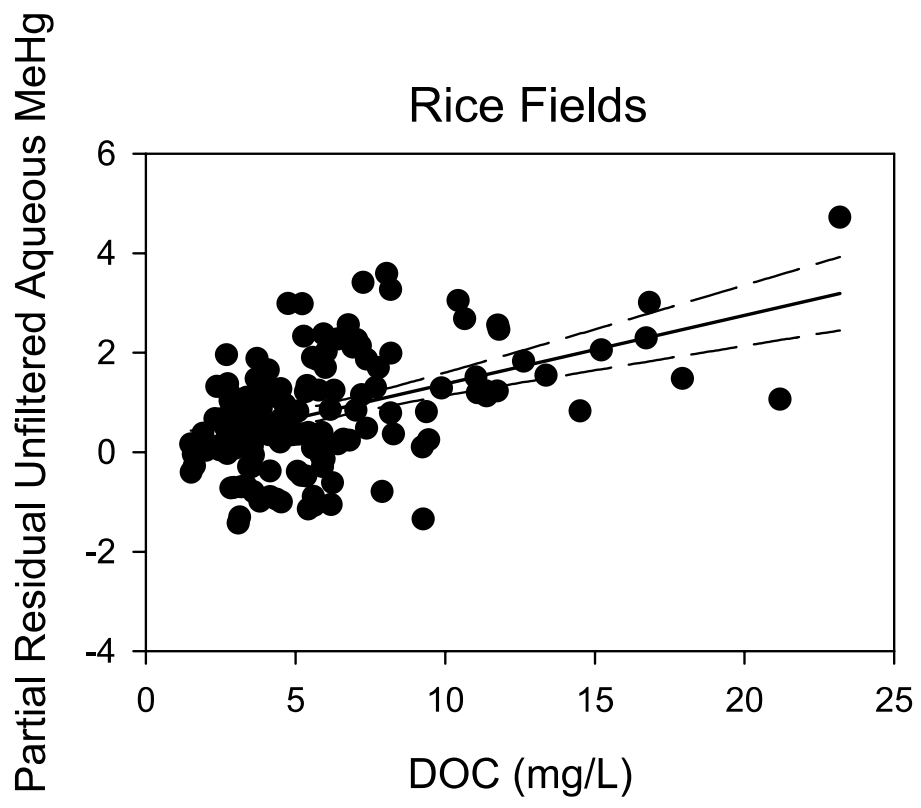

Figure 19. Relationship between aqueous methylmercury (MeHg) concentrations (unfiltered $\mathrm{ng} / \mathrm{L}$ ) and dissolved organic carbon (DOC) from rice fields in the Cosumnes River Preserve. Methylmercury values are reported as partial residuals from the ANOVA model controlling for treatment, site, and time effects. 

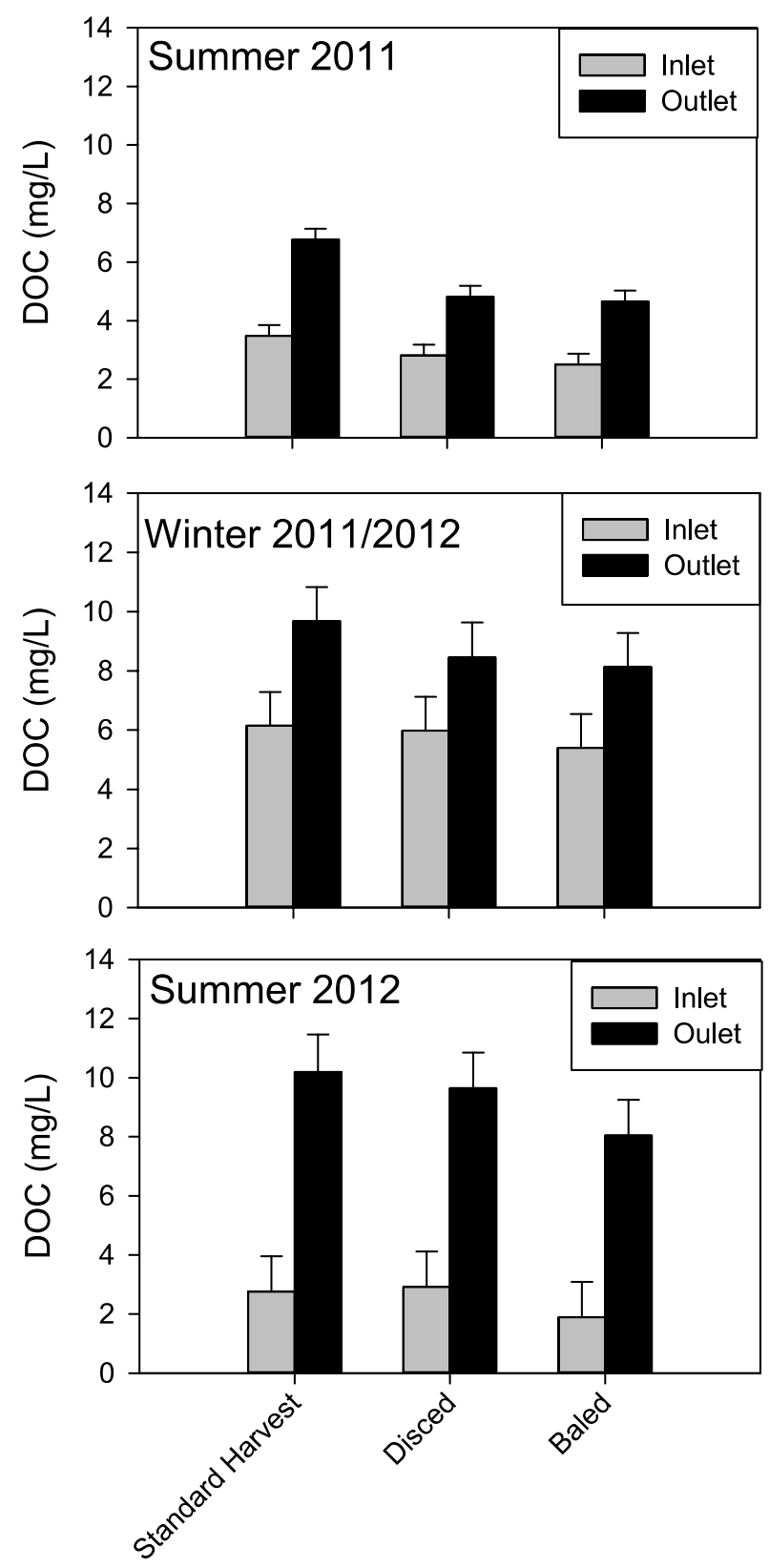

Rice Treatment

Figure 20. Dissolved organic carbon (DOC) concentrations from inlet and outlet surface-water samples of rice fields subjected to three post-harvest rice straw management practices in the Cosumnes River Preserve during summer 2011, winter 2011-12, and summer 2012. Error bars represent standard error. 

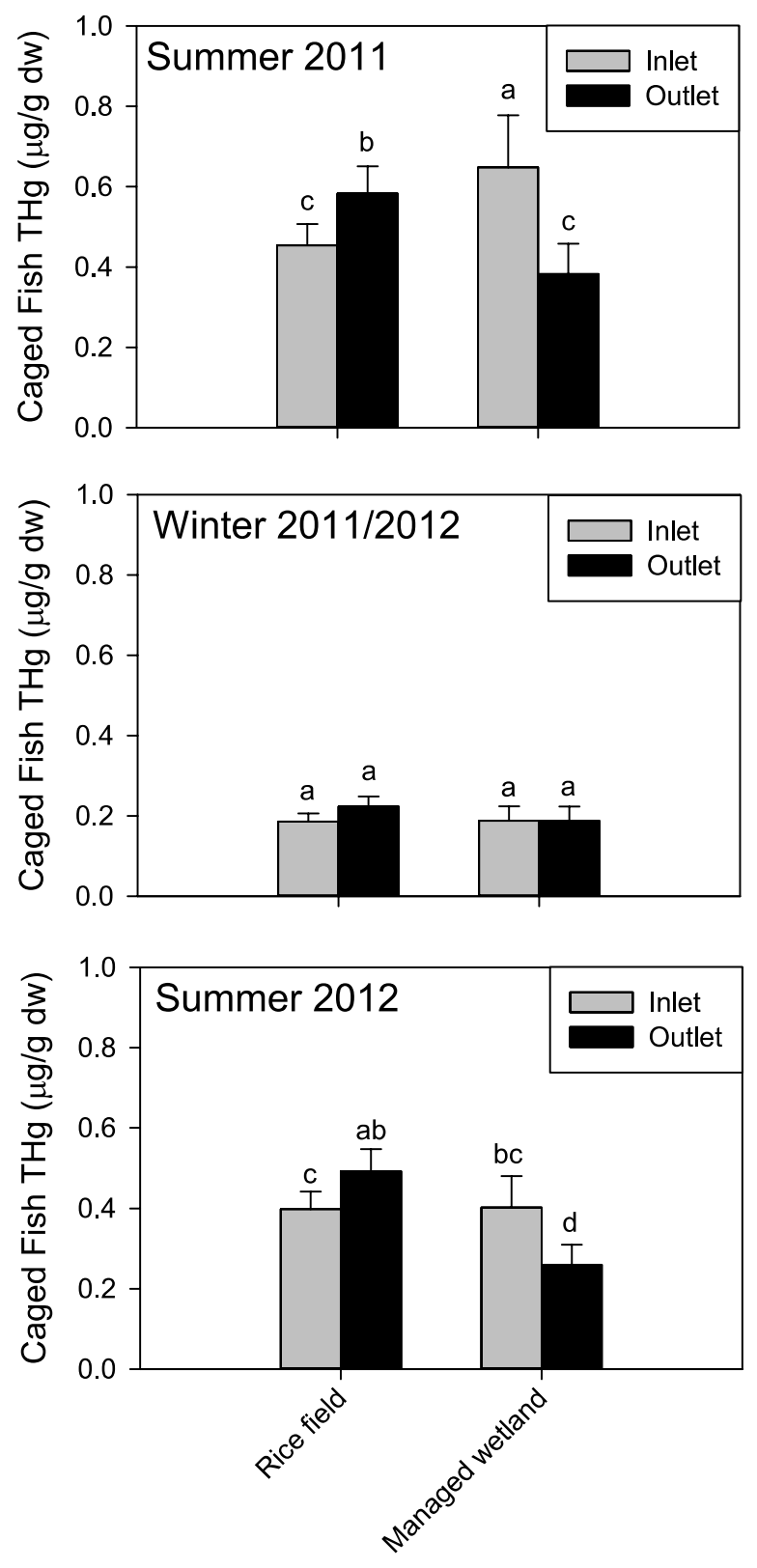

Habitat Type

Figure 21. Caged fish THg concentrations (least-square mean \pm standard error) from inlets and outlets of rice fields and managed seasonal wetlands subjected to identical wetting and drying cycles. Different letters indicate significant differences $(p<0.05)$ based on conditional F-tests. Error bars represent standard error. 


\section{Correlations Between Fish Total Mercury and Water Methylmercury}

We examined the relationships between caged fish $\mathrm{THg}$ concentrations and site-specific seasonal average aqueous $\mathrm{MeHg}$ concentrations using linear regression. In rice fields, geometric mean caged fish $\mathrm{THg}$ concentrations were weakly correlated with seasonal average aqueous $\mathrm{MeHg}$ concentrations during the summer $\left(\mathrm{R}^{2}=0.37\right)$ and winter $\left(\mathrm{R}^{2}=0.30\right)$. The slope of the relationship was approximately $3 \times$ greater in the summer $(0.36)$ than in the winter $(0.11$; fig. 22$)$ in rice fields, indicating that bioaccumulation factors vary with season. Water from wetland sites was sampled during the summer time period and fish $\mathrm{THg}$ concentrations generally were less strongly correlated with aqueous $\mathrm{MeHg}$ concentrations than they were for rice fields $\left(\mathrm{R}^{2}=0.18\right.$; fig. 22$)$ and the slope was similar (0.31) to that of rice fields during the summer.

\section{Net Surface Water Methylmercury Loads}

Net loads of MeHg followed similar trends to the concentration trends with the prevailing differences between seasons: high winter loads and low summer loads (fig. 23). Net loads calculated for the different tested model scenarios are summarized in table 1. Rice fields were predominantly net importers of $\mathrm{MeHg}$ during the summer growing season regardless of treatment. Salt budgets $(\mathrm{Cl}$ and EC) were achieved for at least one model scenario in all fields under the general inflow, outflow and ET constraints. Conductivity performed better for the salt balance than did chloride. Two fields (C9 and C10) did not reach a model solution using inlet and outlet data and required the use of pump data. In general, differences in loads were greater between fields within treatments than among treatments. Unfiltered aqueous $\mathrm{MeHg}$ loads were more variable in winter compared to summer but appear to result in a net export of $\mathrm{MeHg}$ rather than net import (table 1). 

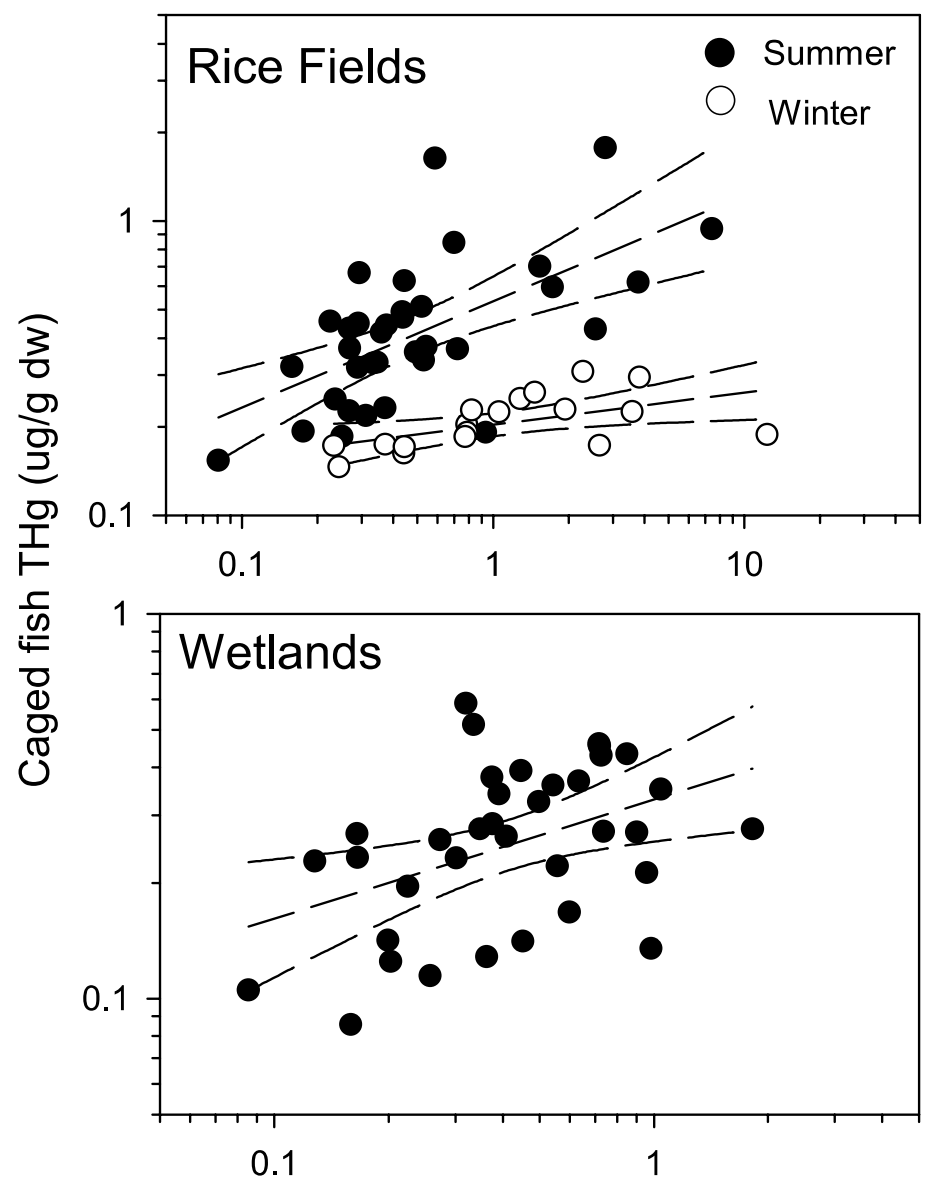

Unfiltered aqueous $\mathrm{MeHg}$ (ng/L)

Figure 22. Relationship between cage-specific mean fish total mercury concentrations and seasonal average aqueous methylmercury concentrations in rice fields (top panel) and seasonal wetlands (bottom panel) during summer (filled circles) and winter (open circles) time periods in the Cosumnes River Preserve. 
MeHg net loads by season $(n=9)$ in ug $m-2$

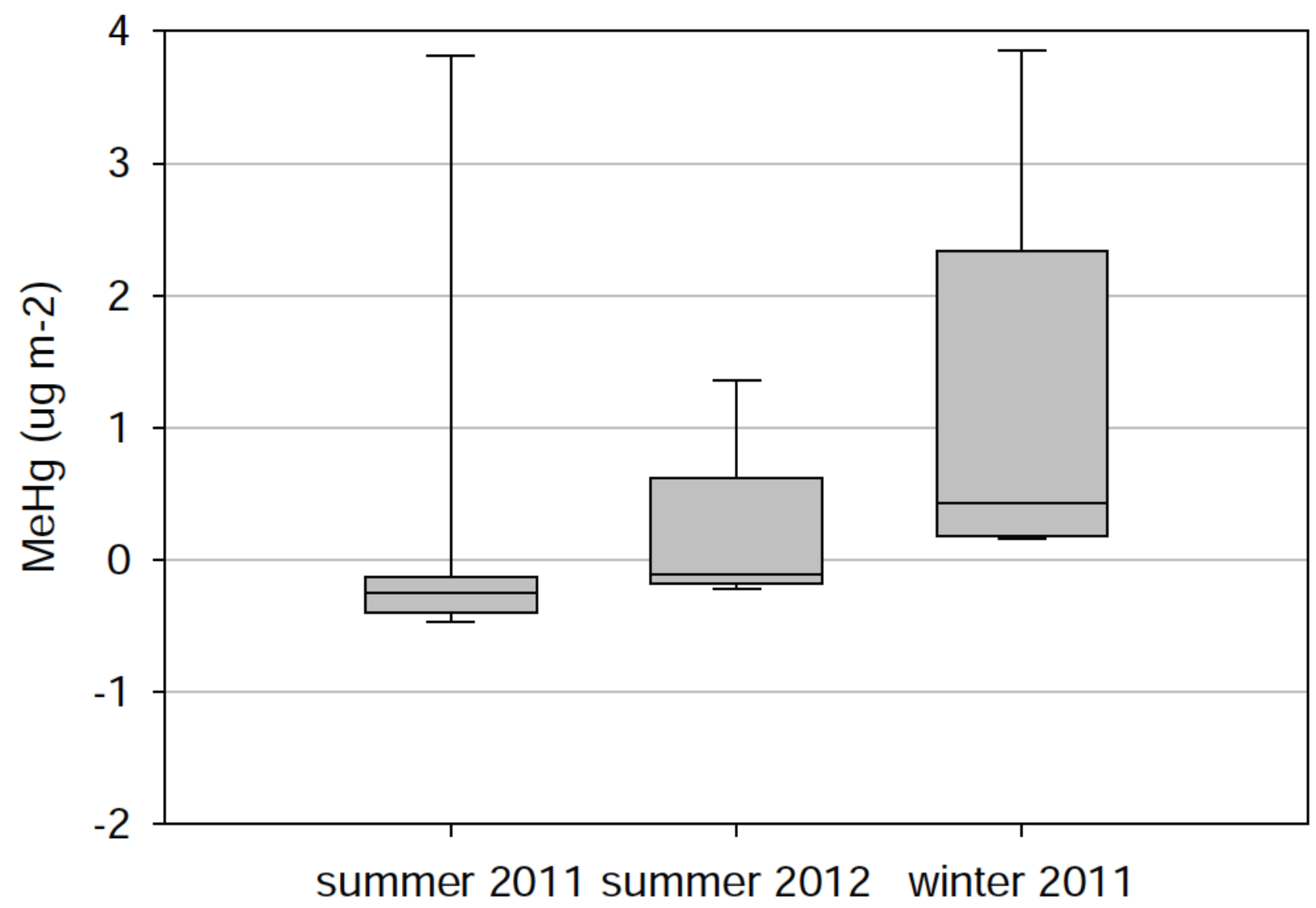

Figure 23. Boxplot showing net methylmercury (MeHg) loads by season in the Cosumnes River Preserve. Solid line in box represents the median; the lower and upper bounds of the gray box represent the $25^{\text {th }}$ and $75^{\text {th }}$ percentiles, respectively; the whiskers represent the minimum and maximum values. 
Table 1. Estimated net methylmercury (MeHg) loads from rice fields. Six unique solutions evaluated with eight scenarios using evapotranspiration (ET), flow, and salt (Cl or EC).

[Negative values indicate a net "loss" or "sink" within the rice field for the period of flooding. "GS (cm)" is the modeled seasonally averaged daily flow at the outlet normalized to the field area given constraints on percent E of ET ( 25 percent in summer, 90 percent in winter). Field area of C10 is estimated. Estimated net $\mathrm{MeHg}$ loads from rice fields for the winter controlled flood period-not uncontrolled flood period in March. Rice field codes: RCD, disked treatment; RHC, standard harvest treatment; RSB, baled treatment. Wetland codes: SWS, dual flood-up and drawdown treatment; SWF, single flood-up and drawdown treatment; PWS, permanent wetland treatment]

\begin{tabular}{|c|c|c|c|c|c|c|c|c|c|c|c|c|c|c|c|c|}
\hline \multirow[b]{3}{*}{ Type } & \multirow[b]{3}{*}{ Test } & \multirow[b]{3}{*}{ Field ID } & \multirow[b]{3}{*}{ Manager } & \multirow{3}{*}{$\begin{array}{l}\text { Area } \\
\text { (ha) }\end{array}$} & \multicolumn{4}{|c|}{ Summer 1 (June-Sept 2011) } & \multicolumn{4}{|c|}{ Winter (Nov 2011 - Feb 2012) } & \multicolumn{4}{|c|}{ Summer 2 (June-Sept 2012) } \\
\hline & & & & & \multicolumn{2}{|c|}{$\begin{array}{c}\text { Model } \\
\text { convergence1 }\end{array}$} & \multicolumn{2}{|c|}{ MeHg load (ug/m2) } & \multicolumn{2}{|c|}{$\begin{array}{c}\text { Model } \\
\text { convergence1 }\end{array}$} & \multirow{2}{*}{$\begin{array}{l}\text { MeHg load } \\
\text { Average }\end{array}$} & \multirow{2}{*}{$\begin{array}{c}\text { (ug/m2) } \\
\text { Stdev }\end{array}$} & \multicolumn{2}{|c|}{$\begin{array}{c}\text { Model } \\
\text { convergence1 }\end{array}$} & \multirow{2}{*}{$\begin{array}{l}\text { MeHg load } \\
\text { Average }\end{array}$} & \multirow{2}{*}{$\begin{array}{r}\text { (ug/m2) } \\
\text { Stdev }\end{array}$} \\
\hline & & & & & Good & Fair & Average & Stdev & Good & Fair & & & Good & Fair & & \\
\hline Rice & $\mathrm{RCD}$ & B14 & $\mathrm{R}$ & 26.8 & 4 & 1 & -0.25 & 0.04 & 4 & 1 & 0.17 & 0.05 & 6 & 1 & -0.18 & 0.02 \\
\hline Rice & RCD & B21 & $\mathrm{R}$ & 14 & 4 & 2 & -0.47 & 0.01 & 1 & 1 & 2.27 & 2.24 & 5 & 1 & -0.08 & 0.08 \\
\hline Rice & $\mathrm{RCD}$ & $\mathrm{C} 10$ & M & 5 & 1 & 2 & 1.46 & 2.04 & 2 & 0 & 3.00 & 0.32 & 3 & 2 & 1.36 & 4.91 \\
\hline Rice & RHC & B7 & $\mathrm{R}$ & 10.5 & 3 & 2 & -0.11 & 0.00 & 2 & 2 & 0.25 & 0.34 & 2 & 2 & -0.16 & 0.00 \\
\hline Rice & RHC & B13 & $\mathrm{R}$ & 13.9 & 2 & 1 & -0.14 & 0.00 & 1 & 1 & 1.07 & 0.84 & 3 & 0 & -0.21 & 0.03 \\
\hline Rice & RHC & C9 & M & 24.1 & 2 & 1 & -0.45 & 0.01 & 5 & 1 & 0.19 & 0.20 & 3 & 0 & 0.70 & 0.27 \\
\hline Rice & RSB & B19 & $\mathrm{R}$ & 8.7 & 3 & 2 & -0.14 & 0.00 & 3 & 2 & 0.31 & 0.13 & 2 & 2 & -0.12 & 0.03 \\
\hline Rice & RSB & $\mathrm{C} 4$ & M & 18.2 & 0 & 3 & -0.36 & 0.03 & 5 & 1 & 0.16 & 0.24 & 2 & 2 & -0.09 & 0.05 \\
\hline Rice & RSB & $\mathrm{C} 6$ & $\mathrm{M}$ & 14.9 & 1 & 1 & -0.27 & 0.03 & 2 & 0 & 0.88 & 0.35 & 6 & 0 & 0.70 & 0.55 \\
\hline Rice & all & all & & & & & -0.14 & median & & & 0.31 & median & & & -0.09 & median \\
\hline wetland & SWS & 19 & BLM & 5.7 & 0 & 0 & NR & NR & $\mathrm{ND}$ & ND & ND & ND & 4 & 0 & 0.67 & 0.13 \\
\hline wetland & SWS & 23 & BLM & 4.9 & 0 & 0 & NR & NR & ND & ND & ND & ND & 6 & 0 & 0.20 & 0.18 \\
\hline wetland & SWS & 24 & BLM & 4 & 0 & 0 & NR & NR & ND & ND & ND & ND & 2 & 1 & -0.82 & 0.23 \\
\hline wetland & SWF & $20^{*}$ & BLM & 13.8 & 0 & 0 & NR & NR & ND & ND & ND & ND & 5 & 0 & -0.19 & 0.18 \\
\hline wetland & SWF & $25^{*}$ & BLM & 4.5 & 2 & 2 & -1.57 & 0.96 & ND & ND & ND & ND & 2 & 0 & -0.90 & 0.17 \\
\hline wetland & SWF & $26^{*}$ & BLM & 3.6 & 0 & 0 & NR & NR & ND & ND & ND & ND & 4 & 0 & -0.77 & 0.17 \\
\hline wetland & PWE & $28 *$ & BLM & 4 & 0 & 1 & -0.13 & NA & ND & ND & ND & ND & 0 & 0 & NR & NR \\
\hline wetland & PWE & $3 A^{*}$ & BLM & 4 & 3 & 1 & -0.27 & 0.01 & ND & ND & ND & ND & 2 & 2 & -0.09 & 0.05 \\
\hline wetland & PWS & $\mathrm{TC} 1 *$ & BLM & 3 & 5 & 2 & 0.30 & 0.61 & $\mathrm{ND}$ & ND & ND & ND & 2 & 2 & -0.17 & 0.03 \\
\hline
\end{tabular}

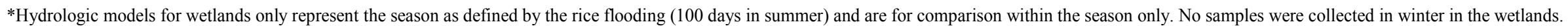

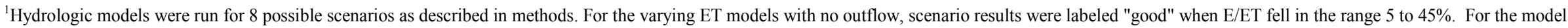
where E/ET was held constant ( $25 \%$ summer, $90 \%$ winter) and flow varied, scenario results were labeled "good" if the flow was between -0.1 and $2 \mathrm{~cm}$. The scenarios labeled as "fair" fall out of the range of acceptance criteria yet may represent reasonable conditions that deviate from the model assumptions, but should be viewed with scrutiny.

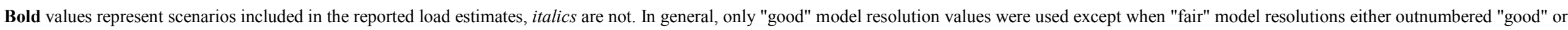
where there was only one "good" value.

$\mathrm{NR}=$ no resolution/convergence of the model.

$\mathrm{ND}=$ no data.

$\mathrm{NA}=$ not applicable 


\section{Discussion}

This study examined the variation in fish $\mathrm{Hg}$ and aqueous $\mathrm{MeHg}$ concentrations across managed and unmanaged aquatic habitats of the Preserve in Sacramento-San Joaquin River Delta, as well as tested the influence of a range of wetland management and rice harvest strategies on $\mathrm{Hg}$ concentrations and cycling. Our results suggest that even within a relatively constrained geographic area, such as the Preserve, $\mathrm{Hg}$ concentrations can differ substantially among freshwater habitats with similar source water. Our results also suggest that land- and water-management activities can have strong influences on $\mathrm{Hg}$ cycling. We found large, yet opposing, seasonal variation in fish $\mathrm{Hg}$ concentrations and aqueous $\mathrm{MeHg}$ concentrations, despite the fact that $\mathrm{Hg}$ concentrations in fish within a given season were somewhat correlated with their respective site-specific aqueous $\mathrm{MeHg}$ concentrations. Overall, caged fish THg concentrations were highest in rice fields relative to other wetland, slough, or riverine habitats. In fact, $\mathrm{Hg}$ concentrations in caged fish from rice field outlets during the summer were twice as high as those from any other habitat type, even managed wetlands subjected to identical hydrological regimes. This suggests that there may be inherent properties within rice fields that enhance MeHg production and bioaccumulation in comparison with other similar wetland types.

Our results suggest that the experimental post-harvest rice straw management techniques strongly influenced $\mathrm{Hg}$ bioaccumulation, and to a lesser extent $\mathrm{Hg}$ export. In particular, the more common standard rice harvest practices resulted in the lowest fish $\mathrm{Hg}$ concentrations. In fact, average caged fish THg concentrations were 1.3 and $1.6 \times$ higher at rice field outlets than their inlets for chopped and disked and chopped and baled fields, whereas $\mathrm{THg}$ concentrations in caged fish from outlets of chopped-only (standard harvest) fields were similar to their inlets. These results at the Preserve are in contrast to a similar caged-fish study at the Yolo Bypass Wildlife Area, where caged fish $\mathrm{Hg}$ concentrations were more than $3 \times$ higher at the outlets than at the inlets of standard harvested fields (Ackerman and Eagles-Smith, 2010). There were rapid increases in caged fish THg concentrations over the 30 day deployment time period in both studies. At the Yolo Bypass Wildlife Area, caged fish $\mathrm{THg}$ concentrations increased 5.8 and $12.1 \times$ over initial concentrations in wild rice and white rice, respectively (Ackerman and Eagles-Smith, 2010). Fish THg concentrations in white rice fields at the Preserve increased $5 \times$ to $11 \times$ above initial concentrations in chopped-only (standard harvest) fields, $8 \times$ to $15 \times$ above initial concentrations in chopped and disked fields, and $9 \times$ to $28 \times$ above initial concentrations in chopped and baled fields. Thus, even though the difference between inlets and outlets was less in chopped-only (standard harvest) rice fields at the Preserve than at the Yolo Bypass, the overall proportional increase from introduction to removal was similar; it is just that fish $\mathrm{Hg}$ concentrations increased more at the inlets at the Preserve than at the Yolo Bypass. In sum, the differences among post-harvest rice treatments suggests that land-management activities associated with rice farming can have strong implications on in situ $\mathrm{Hg}$ production and bioaccumulation, but removal or burial of residual rice straw may exacerbate rather than ameliorate $\mathrm{MeHg}$ bioaccumulation in rice fields.

This study was, in part, designed to test whether post-harvest carbon management could be an effective tool for reducing $\mathrm{Hg}$ methylation and bioaccumulation in rice fields. This is an important question because labile organic carbon is such as integral component of the Hg cycle (Driscoll and others, 1995; Lambertsson and Nilsson, 2006) and the standard practice of flooding residual rice straw to facilitate decomposition could unintentionally stimulate $\mathrm{MeHg}$ production (Marvin-Dipasquale and others, 2013; Windham-Myers and others, 2014b). Our results were contrary to our hypothesis that removing rice straw (and its associated carbon) from rice fields, or burying straw below the upper soil profile, would decrease $\mathrm{MeHg}$ concentrations in rice fields during the subsequent growing season. Instead, caged fish THg concentrations were actually highest and showed the greatest proportional 
increase from inlets to outlets in chopped and baled fields, followed by chopped and disked fields. Total $\mathrm{Hg}$ concentrations in caged fish were lowest in chopped-only (standard harvest) fields, and there was little difference between inlets and outlets. These results suggest that rice straw-associated carbon may not be a limiting resources for Hg-methylating bacteria, and thus post-harvest residual carbon control may be decoupled from $\mathrm{Hg}$ cycling processes in subsequent growing seasons. During the summer, DOC concentrations were slightly lower in chopped and baled and chopped and disked fields than in chopped-only (standard harvest) fields, but data from a companion study on carbon responses in these fields indicates that the percentage of plant biomass remaining in the treatment fields post-harvest was only slightly less than in the chopped-only standard harvest fields (Lisamarie Windham-Myers, U.S. Geological Survey, unpub. data, 2014). This suggests that management practices may have had only a limited effect on reducing the available carbon within the field, and the alternative two treatments either exacerbated $\mathrm{Hg}$ methylation and bioaccumulation, or that other field-level processes have a greater influence on $\mathrm{Hg}$ cycling than straw removal (baling) and disking it into the soil.

Although there was a $5 \times$ to $28 \times$ increase in caged fish $\mathrm{THg}$ concentrations over the 30 -day time period from deployment to retrieval in rice fields during the summer, caged fish $\mathrm{Hg}$ concentrations only increased $1.4 \times$ during the winter. Conversely, aqueous $\mathrm{MeHg}$ concentrations and $\mathrm{MeHg}$ exports were $1.5 \times$ and nearly $4 \times$ higher, respectively, in winter than in summer. This result is similar to those from the nearby Yolo Bypass Wildlife Area, where average daily $\mathrm{MeHg}$ exports from managed wetlands and rice fields were substantially higher in winter than in summer (Bachand and others, 2014b; Fleck and others, 2014; Windham-Myers and others, 2014a). This divergence in seasonal patterns between aqueous $\mathrm{MeHg}$ concentrations and export in comparison to in situ $\mathrm{Hg}$ bioaccumulation is notable. The competing seasonal windows for in situ risk to wetland-dependent biota versus aqueous $\mathrm{MeHg}$ export and loading suggest that treatments to control MeHg during one season may not ameliorate its risks in another season. For example, summer and spring time periods are critical timeframes for wildlife reproduction (Eagles-Smith and Ackerman, 2009), which also is a highly sensitive life history stage for $\mathrm{MeHg}$ exposure. Conversely, $\mathrm{MeHg}$ loads in, and export from, rice fields in the Preserve increased substantially during the winter. Site-specific caged fish $\mathrm{THg}$ concentrations were correlated with aqueous $\mathrm{MeHg}$ concentrations during both summer and winter seasons, suggesting that aqueous $\mathrm{MeHg}$ concentrations drive fish THg concentrations in both seasons, but the partitioning between the two matrices appear seasonally decoupled and no single bioaccumulation factor would be useful for converting water $\mathrm{Hg}$ concentrations to fish $\mathrm{Hg}$ concentrations. The specific mechanisms for this are unclear, but could be related to factors such as reduced consumption rates in fishes or partitioning of aqueous $\mathrm{MeHg}$ between dissolved and particulate fractions. For example, the average change in fish size during the winter time period was minimal, whereas fish grew by 1.4 and $3.5 \mathrm{~mm}$ per month during the first and second summer deployments, respectively. The winter and summer decoupling in aqueous $\mathrm{MeHg}$ versus fish $\mathrm{Hg}$ concentrations highlights the variability in bioaccumulation factors over time within a given site, and suggests that the use of global bioaccumulation factors can be of limited value if timeframe of sampling is not carefully controlled for in the sampling and statistical analyses.

Managed wetland treatments also yielded different results for aqueous $\mathrm{MeHg}$ concentrations and caged fish $\mathrm{Hg}$ bioaccumulation. Similar to rice fields, caged fish $\mathrm{THg}$ concentrations in managed wetlands increased from inlets to outlets in permanently flooded managed wetlands, although concentrations were substantially lower in permanent wetlands than in rice fields. Similarly, in the nearby Yolo Bypass Wildlife Area, THg concentrations were lower in caged mosquitofish after a 60day deployment in permanent wetlands than in caged fish from white or wild rice fields (Ackerman and Eagles-Smith, 2010). For seasonal wetlands, we found up to a two-fold decrease from inlets to outlets in both single (fall only) drawdown and flood-up and dual (fall and spring) drawdown and flood-up 
seasonal wetlands at the Cosumnes River Preserve. Aqueous $\mathrm{MeHg}$ concentrations also displayed a somewhat similar pattern in seasonal wetlands, although the high variability in $\mathrm{MeHg}$ measurements in water limited our interpretation. The substantial decrease from inlets to outlets in the seasonal wetlands was unexpected, particularly given the proximity of outlets to inlets, which generally were separated by less than $100 \mathrm{~m}$. We did not test for mechanisms responsible for this pattern, but these findings may be the result of particle settling and photodemethylation near the outlet drains. The inlets of these wetlands were shallow and densely vegetated with aquatic macrophytes, whereas outlet drains tended to be $1 \mathrm{~m}$ or greater in depth and were surrounded by abundant areas of open water with little or no macrophyte density. These results are in apparent contrast with our results from the Yolo Bypass where Hg concentrations increased from inlets to outlets in seasonal wetlands. This apparent dichotomy of results from two sites suggests that classifying these wetlands simply based upon hydrological regime may not adequately characterize implications for $\mathrm{Hg}$ cycling. Instead, seasonal wetlands at the Cosumnes River Preserve were more similar in their characteristics to permanent wetlands at Yolo Bypass, and permanent wetlands at the Cosumnes River Preserve were more similar to the characteristics of seasonal wetlands at Yolo Bypass. The key differences appear to be the highly dense vegetation in permanent wetlands at the Cosumnes River Preserve and in seasonal wetlands at Yolo Bypass, and the relative open water and deeper water depths of seasonal wetlands at the Cosumnes River Preserve and permanent wetlands at Yolo Bypass. These results are worthy of follow-up study to determine whether open-water areas in wetlands can decrease $\mathrm{MeHg}$ export and bioaccumulation.

Organic carbon is a critical component of the $\mathrm{Hg}$ cycle for several reasons. It facilitates transfer of $\mathrm{MeHg}$ and inorganic $\mathrm{Hg}$ through aquatic systems (Driscoll and others, 1995) and it also fuels $\mathrm{MeHg}$ production (Lambertsson and Nilsson, 2006). The influence of organic carbon on $\mathrm{Hg}$ cycling is dependent on both the quantity and quality of available carbon (Dittman and others, 2010). DOC concentrations were positively correlated with aqueous $\mathrm{MeHg}$ concentrations in rice fields, permanent wetlands, and single-drawdown seasonal wetlands, but not in dual drawdown seasonal wetlands. The increase in DOC concentrations from inlets to outlets in rice fields also matched the pattern in aqueous $\mathrm{MeHg}$ concentrations and caged fish THg bioaccumulation. Within rice fields, we manipulated postharvest carbon availability on the fields by either disking the residual rice straw into the soil or baling and removing the straw from the fields. DOC concentrations were highest in the standard harvest fields and lowest in the baled fields, whereas the DOC concentrations in the disked fields did not statistically differ from either standard harvest or baled fields. Thus, it appears that rice straw management may have had a measurable influence on surface-water DOC concentrations. Caged fish $\mathrm{Hg}$ concentrations were highest in baled fields and lowest in standard harvest fields. The mechanisms behind these potentially contradictory results are unclear but highlight the complexities of the role that carbon play in Hg transport, methylation, and bioaccumulation.

Rice wetlands are emerging as important habitats for $\mathrm{Hg}$ cycling in areas where they are abundant on the landscape (Windham-Myers and others, 2014a). In California, rice wetlands occupy more than twice the area of natural wetlands (Windham-Myers and others, 2014a) and occupy more than 162 million ha globally (Mitsch and others, 2010). They also provide important habitat for wintering birds. Recent work has documented elevated $\mathrm{Hg}$ concentrations within rice fields in China (Li and others, 2010; Zhang and others, 2010), as well as the Central Valley of California (Windham-Myers and others, 2014a, Marvin-DiPasquale and others, 2014). Although pollution from mining and industrial activities played a role in $\mathrm{Hg}$ contamination in both regions, the evidence for enhanced $\mathrm{MeHg}$ 
production is suggestive of unique processes within rice wetlands that may exacerbate $\mathrm{MeHg}$ risk (Windham-Myers and others, 2014b). Indeed, the combination of cyclical wetting and drying, sulfate application, and high productivity are all factors that potentially enhanced $\mathrm{MeHg}$ production. Yet, in comparison with managed seasonal wetlands subjected to the identical hydrological regime, $\mathrm{Hg}$ bioaccumulation was at least 50 percent greater in rice fields than in seasonal wetlands. The mechanisms associated with these differences are unclear, but may be related to rice plant influences on carbon cycling within rice wetlands, as well as advective transport of $\mathrm{Hg}$ into the root zone. Our understanding of the influence of wetland plants on $\mathrm{MeHg}$ cycling is still developing, but recent studies have clearly shown that physiological processes in the root zone associated with plant metabolism are important in regulating the $\mathrm{Hg}$ cycle. Devegetation experiments with rice plants and other wetland plant species result in substantially reduced microbial activity and $\mathrm{MeHg}$ production relative to adjacent vegetated plots (Windham-Myers and others, 2014b). Moreover, root density within rice fields is directly correlated with the $\mathrm{Hg}$ methylation rate constant (Windham-Myers and others, 2014b).

In summary, our results suggest that complex processes control aqueous $\mathrm{MeHg}$ and fish $\mathrm{Hg}$ concentrations in managed wetlands and rice fields. In particular, processes within rice fields appear to increase aqueous $\mathrm{MeHg}$ concentrations and fish $\mathrm{THg}$ concentrations relative to other managed wetland types, and those processes appear to be related to post-harvest straw management such that $\mathrm{Hg}$ concentrations were highest in the two experimental post-harvest treatments. However, the mechanisms associated with these patterns cannot be discerned here and are likely reflective of in situ biogeochemical processes in response to the different post-harvest management techniques. Moreover, the decoupling between summer-time and winter-time aqueous $\mathrm{MeHg}$ concentrations relative to caged fish bioaccumulation rates indicates that the processes that are most important for in situ wildlife risk are likely different than those that drive aqueous $\mathrm{MeHg}$ concentrations and discharge. Additionally, the decrease in caged fish THg concentrations in managed seasonal wetlands, from inlet to outlet, indicate that some wetlands could be important sinks for $\mathrm{MeHg}$ in the region and further research is needed to better understand this finding.

\section{Acknowledgments}

This study was funded by the Central Valley Regional Water Quality Control Board through a U.S. Environmental Protection Agency 319(h) grant, and by the U.S. Geological Survey and Bureau of Land Management. The team thanks Diane Beaulaurier for her efforts with contract management and project coordination. We also thank Janis Cooke and other staff at the Regional Water Quality Control Board for insight and implementation support. Logistical support was provided by Mariah Brumbaugh, Mark Ackerman, and Holden Brink of the Cosumnes River Preserve. We are grateful to Demetri Dokas of the Sacramento-Yolo County Vector Control District for providing mosquitofish for this study, and Robert Magenheimer and Mike Johnson for their farming efforts and implementation of experiments post-harvest straw management techniques. We also thank Nick Baker, Kevin Donner, Angela Hansen, Alex Hartman, Garth Herring, Mark Herzog, Branden Johnson, Robin Keister, Kathleen Keating, Brandon Kowalski, John Pierce, Tully Rohrer, Kiira Siitari, Liz Stumpner, Trevor Watts, and many others for field and laboratory support. We are grateful to Chris Eckley, Janis Cooke, and Diane Beaulaurier for insightful comments on earlier versions of this report. 


\section{References Cited}

Ackerman, J.T., and Eagles-Smith, C.A., 2010, Agricultural wetlands as potential hotspots for mercury bioaccumulation: Experimental evidence using caged Fish: Environmental Science and Technology, v. 44, no. 4, p. 1,451-1,457.

Ackerman, J.T., Takekawa, J.Y., Orthmeyer, D.L., Fleskes, J.P., Yee, J.L., and Kruse, K.L., 2006, Spatial use by wintering greater white-fronted geese relative to a decade of habitat change in California's Central Valley: Journal of Wildlife Management, v. 70, no. 4, p. 965-976.

Bachand, P.A., Bachand, S., Fleck, J., Anderson, F., and Windham-Myers, L., 2014a, Differentiating transpiration from evaporation in seasonal agricultural wetlands and the link to advective fluxes in the root zone: Science of the Total Environment, v. 484, p. 232-248.

Bachand, P.A., Bachand, S.M., Fleck, J.A., Alpers, C.N., Stephenson, M., and Windham-Myers, L., 2014b, Methylmercury production in and export from agricultural wetlands in California, USA: The need to account for physical transport processes into and out of the root zone: Science of the Total Environment, v. 484, p. 249-262.

Bloom, N.S., 1989, Determination of picogram levels of methyl mercury by aqueous phase ethylation, followed by cryogenic gas chromatography with cold vapour atomic fluorescence detection: Journal of Fisheries and Aquatic Science, v. 46, p. 1131-1138.

Dittman, J.A., Shanley, J.B., Driscoll, C.T., Aiken, G.R., Chalmers, A.T., Towse, J.E., and Selvendiran, P., 2010, Mercury dynamics in relation to dissolved organic carbon concentration and quality during high flow events in three northeastern US streams: Water Resources Research, v. 46.

Driscoll, C.T., Blette, V., Yan, C., Schofield, C.L., Munson, R., and Holsapple, J., 1995, Role of dissolved organic-carbon in the chemistry and bioavailability of mercury in remote Adirondack lakes: Water Air and Soil Pollution, v. 80, no. 1-4, p. 499-508.

Driscoll, C.T., Mason, R.P., Chan, H.M., Jacob, D.J., and Pirrone, N., 2013, Mercury as a global pollutant: Sources, pathways, and effects: Environmental Science and Technology, v. 47, no. 10, p. 4,967-4,983.

Eagles-Smith, C.A., and Ackerman, J.T., 2009, Rapid changes in small fish mercury concentrations in estuarine wetlands: Implications for wildlife risk and monitoring programs: Environmental Science and Technology, v. 43, no. 22, p. 8,658-8,664.

Fleck, J.A., Gill, G., Bergamaschi, B.A., Kraus, T.E., Downing, B.D., and Alpers, C.N., 2014, Concurrent photolytic degradation of aqueous methylmercury and dissolved organic matter: Science of the Total Environment, v. 484, p. 263-275.

Fleming, E.J., Mack, E.E., Green, P.G., and Nelson, D.C., 2006, Mercury methylation from unexpected sources-Molybdate-inhibited freshwater sediments and an iron-reducing bacterium: Applied and Environmental Microbiology, v. 72, no. 1, p. 457-464.

Fleskes, J.P., Perry, W.M., Petrik, K.L., Spell, R., and Reid, F., 2005, Change in area of winter-flooded and dry rice in the Northern Central Valley of California determined by satellite imagery: California Fish and Game, v. 91, no. 3, p. 207-215.

Frayer, W.E., Peters, D.D., and Pywell, H.R., 1989, Wetlands of the California Central Valley Status and Trends-1939 to mid-1980s: U.S. Department of Interior Fish and Wildlife Service.

Gilmour, C.C., Henry, E.A., and Mitchell, R., 1992, Sulfate stimulation of mercury methylation in freshwater sediments: Environmental Science and Technology, v. 26, no. 11, p. 2,281-2,287.

Goulden, M.L., Litvak, M., Miller, S.D., 2007. Factors that control Typha marsh evapotranspiration: Aquatic Botany, v. 86, p. 97-106.

Hall, B.D., Aiken, G.R., Krabbenhoft, D.P., Marvin-DiPasquale, M., and Swarzenski, C.M., 2008, Wetlands as principal zones of methylmercury production in southern Louisiana and the Gulf of Mexico region: Environmental Pollution, v. 154, no. 1, p. 124-134. 
Heim, W.A., Coale, K.H., Stephenson, M., Choe, K., Gill, G.A., and Foe, C., 2007, Spatial and habitat-based variations in total and methyl mercury concentrations in surficial sediments in the San Francisco BayDelta: Environmental Science and Technology, v. 41, p. 3,501-3,507.

Horvat, M., Liang, L., Bloom, N.S., 1993, Comparison of distillation with other current isolation methods for the determination of methyl mercury compunds in low-level environmental samples. 2. Water: Analytica Chimica Acta, v. 282, p. 153-168.

Lambertsson, L., and Nilsson, M., 2006, Organic material-The primary control on mercury methylation and ambient methyl mercury concentrations in estuarine sediments: Environmental Science and Technology, v. 40, no. 6, p. 1,822-1,829.

Li, L., Wang, F., Meng, B., Lemes, M., Feng, X., and Jiang, G., 2010, Speciation of methylmercury in rice grown from a mercury mining area: Environmental Pollution, v. 158, no. 10, p. 3,103-3,107.

Marvin-Di Pasquale, M., and Agee, J.L., 2003, Microbial mercury cycling in sediments of the San Francisco Bay-Delta: Estuaries, v. 26, no. 6, p. 1,517-1,528.

Marvin-Dipasquale, M., Windham-Myers, L., Agee, J.L., Kakouros, E., Kieu, L.H., Fleck, J.A., Alpers, C.N., and Stricker, C.A., 2014, Methylmercury production in sediment from agricultural and nonagricultural wetlands in the Yolo Bypass, California, USA: Science of the Total Environment, v. 484, p. 288-299.

Mitsch, W.J., Nahlik, A., Wolski, P., Bernal, B., Zhang, L., and Ramberg, L., 2010, Tropical wetlandsSeasonal hydrologic pulsing, carbon sequestration, and methane emissions: Wetlands Ecology and Management, v. 18, no. 5, p. 573-586.

Singer, M.B., Aalto, R., James, L.A., Kilham, N.E., Higson, J.L., and Ghoshal, S., 2013, Enduring legacy of a toxic fan via episodic redistribution of California gold mining debris: Proceedings of the National Academy of Sciences of the United States of America, v. 110, no. 46, p. 18,436-18,441.

Ullrich, S.M., Tanton, T.W., and Abdrashitova, S.A., 2001, Mercury in the aquatic environment-A review of factors affecting methylation: Critical Reviews in Environmental Science and Technology, v. 31, no. 3, p. 241-293.

Windham-Myers, L., Fleck, J.A., Ackerman, J.T., Marvin-Dipasquale, M., Stricker, C.A., Heim, W.A., Bachand, P.A., Eagles-Smith, C.A., Gill, G., Stephenson, M., and Alpers, C.N., 2014a, Mercury cycling in agricultural and managed wetlands - A synthesis of methylmercury production, hydrologic export, and bioaccumulation from an integrated field study: Science of the Total Environment, v. 484, p. 221-231.

Windham-Myers, L., Marvin-Dipasquale, M., Kakouros, E., Agee, J.L., Kieu le, H., Stricker, C.A., Fleck, J.A., and Ackerman, J.T., 2014b, Mercury cycling in agricultural and managed wetlands of California, USA - Seasonal influences of vegetation on mercury methylation, storage, and transport: Sci Total Environ, v. 484, p. 308-318.

Windham-Myers, L., Marvin-Dipasquale, M., Krabbenhoft, D.P., Agee, J.L., Cox, M.H., HerediaMiddleton, P., Coates, C., and Kakouros, E., 2009, Experimental removal of wetland emergent vegetation leads to decreased methylmercury production in surface sediment: Journal of Geophysical ResearchBiogeosciences, v. 114, no. G2.

Wood, M.L., Foe, C., Cooke, C.A., and Louie, S.J., 2010, Regional Water Quality Control Board - Central Valley Region, Sacramento - San Joaquin Delta Estuary TMDL for methylmercury: Central Valley Regional Water Quality Control Board, Staff Report.

Zhang, H., Feng, X., Larssen, T., Shang, L., and Li, P., 2010, Bioaccumulation of methylmercury versus inorganic mercury in rice (Oryza sativa L.) grain: Environmental Science and Technology, v. 44, no. 12, p. 4499-4504. 
Publishing support provided by the U.S. Geological Survey Science Publishing Network, Tacoma Publishing Service Center

For more information concerning the research in this report, contact the Director, Forest and Rangeland Ecosystem Science Center U.S. Geological Survey 777 NW 9th Street, Suite 400

Corvallis, Oregon 97330

http://fresc.usgs.gov 


\section{हू}

ֻั)

ब

当.

อ

울

$\frac{7}{0}$

3

อี

罗

号

蛋.

$\stackrel{8}{0}$

몽

오․

\%ั

急

产

旁

뚬

ถู

츨

흘

홀

के

के 